Kennesaw State University

DigitalCommons@Kennesaw State University

Faculty Publications

$7-2010$

\title{
Testing Conflicting Political Economy Theories: Full-Fledged versus Partial-Scope Regional Trade Agreements
}

Xuepeng Liu

Kennesaw State University, xliu6@kennesaw.edu

Follow this and additional works at: http://digitalcommons.kennesaw.edu/facpubs

Part of the Business Commons, and the Growth and Development Commons

\section{Recommended Citation}

Liu, Xuepeng. "Testing Conflicting Political Economy Theories: Full-Fledged Versus Partial-Scope Regional Trade Agreements." Southern Economic Journal 77.1 (2010): 78-103.

This Article is brought to you for free and open access by DigitalCommons@Kennesaw State University. It has been accepted for inclusion in Faculty Publications by an authorized administrator of DigitalCommons@Kennesaw State University. For more information, please contact 


\title{
Testing Conflicting Political Economy Theories?
}

\section{Full-fledged versus Partial-scope Regional Trade Agreements}

\author{
Xuepeng Liu* \\ Assistant Professor of Economics \\ Department of Economics and Finance \\ Coles School of Business \\ Kennesaw State University
}

\begin{abstract}
The median voter approach to trade policies within a Heckscher-Ohlin framework predicts that trade policy is pro-labor; while the lobbying model based on the argument of the free rider problem predicts that trade policy is pro-capital. We test these conflicting political economy theories using data on regional trade agreements (RTAs). Due to the violation of the conditional independence assumption of RTAs, we apply a duration analysis rather than standard binary choice analysis to the RTA panel data. The results show that the prediction of the medianvoter model is supported by the full-fledged free trade areas and customs unions (FTAs/CUs); while the prediction of the lobbying model is supported by the partial-scope preferential trade arrangements (PTAs) among developing countries. Our findings hold better for the country pairs with more different capital-labor ratios due to stronger distributional effects of RTAs. The support for the median voter model (lobbying model) is stronger when the two countries in a pair have left-oriented (right-oriented) governments. We also find stronger support for the median voter model for the subset of FTAs/CUs with service coverage and stronger support for the lobbying model for countries that place higher weight on political contribution.
\end{abstract}

Keywords: regional trade agreements; political economy; inequality; median voter model; lobbying model; duration analysis

JEL classification: F15; F12

\footnotetext{
* Department of Economics and Finance, Kennesaw State University, \#0403, Burruss Bldg \#4, Room 322, 1000 Chastain Road, Kennesaw, GA 30144; Email: xliu6@kennesaw.edu; Tel: (770)423-6605. I am grateful to Dan Black, Pushan Dutt, Devashish Mitra, John Pepper and three anonymous referees for helpful comments and suggestions. I also thank the participants at the seminars at Syracuse University and the IMF, and the participants at the North America Econometric Society Meetings for comments.
} 


\section{Introduction}

"A customs union ... duties and other restrictive regulations of commerce (...) are eliminated with respect to substantially all the trade between the constituent territories of the union or at least with respect to substantially all the trade in products originating in such territories, ... A free-trade area shall be understood to mean a group of two or more customs territories in which the duties and other restrictive regulations of commerce (...) are eliminated on substantially all the trade between the constituent territories in products originating in such territories." --- GATT Article XXIV (italics added by author)

"Notwithstanding the provisions of Article I of the General Agreement, contracting parties may accord differential and more favorable treatment to developing countries, without according such treatment to other contracting parties." --- GATT Enabling Clause (italics added by author)

One of the pillars of the GATT/WTO rules is nondiscrimination, which is also called the Most Favored Nation Clause (MFN) in the GATT Article I. It is a commitment that a GATT/WTO member will extend to another member the lowest tariff rates it applies to any other GATT/WTO members. One prominent exception to the MFN Clause is the existence of regional trade agreements (RTAs), which by their very nature are discriminatory. The proliferation of RTAs since late 1950s is fundamentally altering the world trade landscape.

What are the driving forces of regionalism? Besides economic and geographic factors, political economy factors are also important. There are both winners and losers from free trade or RTAs. RTA decisions will be eventually determined by how the preferences of voters, politicians and interest groups are aggregated in policy making process. Therefore it is important to open the black box of the political economy of RTA formation. Different political economy models can have very different predictions. A majority or general interests approach (i.e., the median voter model) in a two-factor Heckscher-Ohlin framework predicts pro-labor trade policy; while a special interests approach (e.g., the lobbying model) based on the argument of free rider problem predicts pro-capital policy. We test these conflicting predictions in RTA formation and find that different models are more relevant for different types of RTAs.

Three types of RTAs are permitted under the GATT/WTO: free trade area (FTA), customs union (CU) and preferential trade arrangement (PTA). ${ }^{1}$ GATT Article XXIV introduced in 1947

\footnotetext{
${ }^{1}$ Other researchers may use PTAs and RTAs interchangeably. PTAs in this paper only refer to the partial-scope arrangements among developing countries under the Enabling Clause, and RTAs include both FTAs/CUs and PTAs.
} 
permits FTAs and CUs as long as such agreements cover "substantially all the trade" in the blocs and do not raise external trade barriers, which are believed essential to promote trade creation and avoid trade diversion. An FTA is an agreement with tariffs eliminated on goods produced in member countries; while a CU is an FTA plus common external tariffs. In 1979, a further exception to nondiscrimination treatment, called the Enabling Clause, was agreed upon for developing countries. This clause allows developing countries to exchange partial tariff preference within preferential trade arrangements (PTAs). ${ }^{2}$ The extent of trade liberalization in PTAs can be very limited. In a famous example, Indonesia, a member of the Association of Southeast Asian Nations (ASEAN) and a country on the equator, excluded major sectors but offered to liberalize imports of snow ploughs from other ASEAN countries (Panagariya, 1994). For this reason, we consider PTAs as partial-scope arrangements and FTAs/CUs as full-fledged agreements.

Previous researchers usually analyze the determinants of RTAs in standard binary choice regressions such as probit and logit. We argue that the traditional binary choice model is inappropriate in panel data analysis due to the conditional independence assumption of the RTA dummy variable. We adopt a duration analysis to correct this problem. Our empirical results show that the prediction of the median voter model is supported by FTA/CU formation; while the lobbying model seems to be more relevant in PTA formation. The support for the conflicting political economy models by FTAs/CUs and PTAs is not surprising given the very different natures of these agreements. The limited sector and trade coverage in PTAs encourages lobbying; while the "substantially all the trade" requirement for FTAs/CUs can serve to reduce lobbying activities. Although most of the FTAs/CUs have long staging periods in internal tariff reduction and some of them may violate the spirit of the Article XXIV, they are offered much less scope for exchanging arbitrary preference than PTAs.

This paper is related to Dutt and Mitra (2002) and Liu (2008), who find empirical support for the median voter model (pro-labor) in trade policies and FTA/CU formation respectively. This paper distinguishes partial-scope from full-fledged RTAs and provides a better

Service agreements signed under the GATS Article V are not considered separately in this paper because they usually parallel to FTAs/CUs in goods. Agreements that are not listed on the WTO RTA website (from other sources, see footnote for the Appendix) are considered as PTAs.

${ }^{2}$ Enabling Clause also allows for differential tariff treatments offered by developed countries to developing countries, such as the General System of Preferences (GSP). GSP is excluded from this paper due to its nonreciprocal nature. Lome/Cotonou agreements are also excluded for the same reason. 
understanding of the conflicting distributional forces behind RTA formation. We show that whether trade policies are pro-labor or pro-capital depends on a number of parameters. In the case of RTA formation, it depends on the types of RTAs, the sector coverage of RTAs, governments' ideological preference and concerns for special vs. general interests, etc.

To reinforce our confidence in the political economy interpretation of our results, we provide the following auxiliary regressions. First, we confirm that the main findings of this paper are indeed driven by distributional effects of RTAs. Within two-factor framework (capital and labor), this distributional effect should be stronger for country pairs with more different capitallabor ratios. We run regressions by sub-samples based on the difference between two countries' capital labor ratios $(\mathrm{K} / \mathrm{L})$. As expected, the support for both models is stronger in the sub-sample with more different K/L compared to those with similar K/L. Second, the pro-labor (pro-capital) trade policy orientation is closely related to the left (right) ideology of a government. If the regressions in this paper indeed capture of political ideology of the governments, the support for the median voter model (lobbying model) should be stronger when the two countries in a pair have left-oriented (right-oriented) governments compared to the rest of the sample. We confirm this with strong empirical evidence. Third, we relate the support of PTAs for the lobbying model to the estimated weight on social welfare by Gawande, Krishna and Olarreaga (2008). We find stronger (weaker) support for the lobbying model in the PTA regressions when we restrict the countries to those with lower (higher) weights on social welfare. Finally, we investigate further the relevance of RTAs' sector coverage to our findings. We argue that our results may be driven by the very different trade coverage requirements of the Article XXIV and the Enabling Clause. Better sector coverage leaves smaller room for lobbying and makes governments care more about the general interests. We explore an alternative way to support this argument by distinguishing different FTAs/CUs based on their coverage of service sectors. Based on this measure we find that the support for the median voter model is stronger when agreements have better coverage.

The above analyses show that we indeed capture the conflicting distributional forces in RTA formation rather than some spurious correlations. Two cautions in the political economy interpretations, however, are worth noting. First, the support of the median voter model should not be taken too literally in the context of direct democracy and single-peaked preference. We can have exactly the same pro-labor policies if a government is simply concerned about 
inequality, as in Limao and Panagariya (2006). Therefore, the median voter model should be taken as a short-hand way to capture the general concerns for popular support, general interests or income equality. Second, the lobbying model considered in this paper is based on the argument of free rider problem as in Rodrik (1986) and is different from the "protection for sale" approach as in Grossman and Helpman (1994) which explains the cross-industry trade policies and offer different predictions for organized and unorganized industries.

The findings in this paper offer some policy implications. Although the support for the median voter model by the FTAs/CUs does not necessarily imply good governance, the support for the lobbying model by PTAs does raise some concerns. An RTA heavily influenced by lobbies usually leads to welfare loss due to trade diversion ("static welfare impact") and prevents the move from regionalism to multilateralism ("dynamic time path"). According to the classic analysis of Viner (1950), an RTA is welfare improving if the trade creation effect dominates the trade diversion effect. Manipulations by special interest groups representing import-competing sectors are often considered a source of trade diversion and "stumbling block" effect. ${ }^{3}$ The recent literature of endogenous trade agreement formation (e.g., Maggi and Rodriguez-Clare, 1998 \& 2007; Mitra, 2002) suggests that trade agreements may serve a commitment device to tie the hand of a politically motivated government or a government with low bargaining power. Ornelas (2005a, 2005b) shows that FTAs lowering the domestic market shares of import-competing sectors reduce their incentives of lobbying for higher external tariffs ("rent dissipation" effects). ${ }^{4}$ The results in this paper imply that a full-fledged RTA compared to a PTA can serve as a better commitment device and has stronger rent dissipation effects, and hence is more likely to be beneficial to multilateral liberalization.

The rest of the paper is organized as follows. Section 2 discusses the theoretical predictions. In Section 3, we explain the testing strategy and econometric methodology. Section 4 describes the data. We report in Section 5 the baseline regression results. Section 6 considers some auxiliary regressions. Section 7 provides some robustness checks and Section 8 concludes.

\footnotetext{
${ }^{3}$ As Bhagwati (1993) argues, RTAs may lead to protection against non-members if producers play the central role in trade policy making. Grossman and Helpman (1995) show in a lobbying model that, to dilute the opposition of pressure groups and increase the probability of RTA adoption, some highly-protected sectors may be excluded from an RTA. Krishna (1998) demonstrates that, if trade policy is used to maximize firms' profits, trade diverting RTAs receive stronger supports politically and more likely become the stumbling block for future multilateral liberalization.

${ }^{4}$ See Estevadeordal, Freund and Ornelas (2008) for some empirical evidence. They study the effects“ of FTAs vs.

CUs on external tariffs of member countries.
} 


\section{Theoretical Predictions}

The Stolper-Samuelson theorem says there are both winners and losers from free trade. Due to the distributional effects of trade, some people may vote for an RTA, while the others against the same RTA. This paper investigates the conflicting distributional forces in RTA formation and the underlying political economy rationales. Different political models, however, can offer the exactly opposite predictions.

Under majority voting, a median voter model predicts that trade policy is pro-labor as in Mayer (1984). The distribution of capital stock in a country is always right-skewed because a small number of rich people usually own disproportionally large share of capital. Accordingly, the person with median capital-labor ratio $(\mathrm{K} / \mathrm{L})$ is always relatively capital-poor respective to the average $\mathrm{K} / \mathrm{L}$ in the country as depicted in Figure 1. Keeping the average K/L constant, higher inequality will lead to an even more right-skewed distribution in $\mathrm{K} / \mathrm{L}$. This in turn will reduce the median K/L and widen the gap between median and mean K/L. Hence the difference between median and mean K/L can be considered as a measure of inequality. Under the median voter model, the country's preference for RTAs is the preference of the median voter. Since the median voter is always relatively capital-poor, trade policy should be pro-labor. According to the Stolper-Samuelson theorem, trade benefits abundant factors but hurts scarce factors. Therefore, pro-labor policy means trade protection in capital-abundant countries but trade liberalization in labor-abundant countries. Because inequality level determines the relative position of a medianvoter in the economy in terms of $\mathrm{K} / \mathrm{L}$, the changes in inequality will affect his/her trade policy preference. Higher inequality will make the median voter more capital-poor; hence make trade policy even more pro-labor. ${ }^{5}$ This in turn causes more protection and lowers likelihood of RTAs in capital-abundant countries, but increases the likelihood of RTAs in labor-abundant countries. The above discussions lead to the following testable prediction.

Proposition 1 (the median voter model): An increase in inequality reduces the desirability of signing an RTA, ceteris paribus, if a country is more capital-abundant relative to its partners. An increase in inequality raises the desirability of signing an RTA, ceteris paribus, if a country is more labor-abundant relative to its partners.

\footnotetext{
${ }^{5}$ Based on Levy (1997) and Liu (2007), Liu (2008) derives the same pro-labor prediction of median voter model in the case of free trade agreements.
} 
A lobbying model can offer the exactly opposite prediction from the median voter model. If we assume that it is easier for capitalists than workers to overcome the free-rider problem in lobbying, then trade policy will be pro-capital. Higher inequality implies that a larger share of capital is in the hands of fewer and bigger capitalists who can carry out collective lobbying more efficiently and make the trade policy even more pro-capital. Rodrik (1986) presents a lobbying model based on free-rider problem. ${ }^{6}$ If we hold constant the aggregate capital stock and total population, a change in inequality can be represented by a change in the number of capitalists. Higher inequality or a decrease in the number of capitalists will help them to reduce the freerider problem and make trade policy more pro-capital. Based on the Stolper-Samuelson theorem, we have the following proposition for the lobbying model:

Proposition 2 (the lobbying model): An increase in inequality raises the desirability of signing an RTA, ceteris paribus, if a country is more capital-abundant relative to its partners. An increase in inequality reduces the desirability of signing an RTA, ceteris paribus, if a country is more labor-abundant relative to its partners.

\section{Testing Strategy and Econometric Method}

\subsection{Empirical Testing Strategy}

An interesting approach to test these theoretical predictions is based on the interaction of income inequality and the capital-labor ratio as in Dutt and Mitra (2002). Using aggregate trade policy data, such as tariffs, quotas and openness, they find empirical support for the medianvoter model proposed by Mayer (1984). We apply this method to RTA formation. We believe that bilateral RTA data analysis can provide a more accurate test for the models because we know exactly which country is relatively more labor or capital abundant in a country pair. GINI coefficient is used as a measure of inequality. Alternatively, the income share of the third quintile of the income distribution $(Q 3)$ is used as a measure of "equality". The two measures are negatively correlated. The coefficients of GINI and $Q 3$ should bear the opposite signs. In the regressions, I estimate the probability of RTA formation as a binary function of a linear index $\left(\mathbf{X}_{\mathrm{ij}} \boldsymbol{\beta}\right): \operatorname{Prob}(R T A=1)=f\left(\mathbf{X}_{\mathrm{ij}} \mathbf{\beta}\right)$, where

$$
\mathbf{X}_{\mathrm{ij}} \boldsymbol{\beta}=\beta_{0}+\beta_{1} G I N I_{i} *\left[\log \left(k_{i}\right)-\log \left(k_{j}\right)\right]+\beta_{2} G I N I_{j} *\left[\log \left(k_{i}\right)-\log \left(k_{j}\right)\right]+\mathbf{X}_{\mathrm{ij}}^{c} \boldsymbol{\beta}^{c}
$$

\footnotetext{
${ }^{6}$ Please note that this model is a modified specific factor model rather than an H-O model.
} 
The function $f($.$) can be estimated by standard logit/probit or complementary log-log link$ function, which will be discussed in details in the next sub-section. The dependent variable is a dummy, indicating whether the two countries $i$ and $j$ had RTA relationship in a given year. $\boldsymbol{X}_{i j}$ is a vector of some economic, geographic, institutional and political variables, and $\boldsymbol{\beta}$ is the corresponding coefficients. The key variables are the two interaction terms. $\mathbf{X}_{\mathrm{ij}}^{c}$ is a vector of control variables and $\boldsymbol{\beta}^{c}$ is the corresponding coefficient vector. Except the geographic covariates, most variables are time-varying. The year subscripts are omitted for simplicity.

The key variables of our interest are the two interaction terms between GINI and the difference in $\log (k)$ of the two countries in a pair (not absolute difference), where $k$ is capital per worker. We can show that, no matter country $i$ is a rich country $\left(k_{i}>k_{j}\right)$ or a poor country $\left(k_{i}<k_{j}\right)$ compared to country $j$, the expected sign of $\beta_{1}$ is always negative according to the median voter model. If $k_{i}>k_{j}$, then $\beta_{1}$ should be negative so that the likelihood of an RTA is decreasing in $G I N I_{i}$ (rich country's inequality). In other words, if $G I N I_{i}$ (rich country) negatively affects the probability of an RTA and the term $\left(\log \left(k_{i}\right)-\log \left(k_{j}\right)\right)$ is positive, then $\beta_{1}$ must be negative. This implies that a more unequal rich country is less likely to sign RTAs because the median voter holding relatively less capital will lose more from freer trade. This effect is augmented by $\left(\log \left(k_{i}\right)-\log \left(k_{j}\right)\right)$. The bigger is the term $\left(\log \left(k_{i}\right)-\log \left(k_{j}\right)\right)$, the stronger the Heckscher-Ohlin distributional effects. On the contrary, if $k_{i}<k_{j}$, then $\left(\log \left(k_{i}\right)-\log \left(k_{j}\right)\right)<0$ and $\beta_{1}$ should still be negative so that the likelihood of an RTA is increasing in $G I N I_{i}$ (poor country's inequality). In other words, if $G I N I_{i}$ (poor country) positively affects the probability of an RTA and the term $\left(\log \left(k_{i}\right)-\log \left(k_{j}\right)\right)$ is negative, then $\beta_{1}$ must be negative. This implies that a more unequal poor country is more likely to sign RTAs because the median voter holding relatively less capital will gain more from freer trade. Similarly, no mater country $i$ is a rich country $\left(k_{i}>k_{j}\right)$ or poor country $\left(k_{i}<k_{j}\right)$ compared to country $j$, the median voter model predicts a positive sign of $\beta_{2}$.

If the lobbying model is instead supported, the coefficient signs discussed above will be reversed. The sign pattern should be exactly the opposite if we substitute $Q 3$ for GINI in regressions. We summarize the expected signs of coefficients as follows. 


\begin{tabular}{ccc}
\hline Variables & Median Voter & Lobby \\
\hline GINIi* $^{*}\left(\log \left(\mathrm{k}_{\mathrm{i}}\right)-\log \left(\mathrm{k}_{\mathrm{j}}\right)\right)$ & - & + \\
GINIj*$^{*}\left(\log \left(\mathrm{k}_{\mathrm{i}}\right)-\log \left(\mathrm{k}_{\mathrm{j}}\right)\right)$ & + & - \\
$\mathrm{Q}^{*} \mathrm{i}^{*}\left(\log \left(\mathrm{k}_{\mathrm{i}}\right)-\log \left(\mathrm{k}_{\mathrm{j}}\right)\right)$ & + & - \\
$\mathrm{Q}^{*} \mathrm{j}^{*}\left(\log \left(\mathrm{k}_{\mathrm{i}}\right)-\log \left(\mathrm{k}_{\mathrm{j}}\right)\right)$ & - & + \\
\hline
\end{tabular}

Many control variables $\left(\boldsymbol{X}^{\boldsymbol{c}}\right)$ are used in the regression. $\left|\log \left(k_{i}\right)-\log \left(k_{j}\right)\right|$ (in absolute value) is included. According to the Heckscher-Ohlin model, its coefficient should be positive, i.e., the larger the difference in endowments the bigger is the gain from an RTA. But the opposite can be true if countries with similar factor endowments or income level have similar production and demand pattern and are more likely to sign an RTA. The sum and the absolute difference of $\log (G D P)$ of the two countries are also used as control variables. They are used to test for the "variety effect" as in Levy (1997). We expect the coefficients of the two variables to be positive and negative respectively, which implies that two bigger and similar countries are more likely to sign an RTA. ${ }^{7}$ Geographic variables such as the great-circle distance and remoteness are also included. Theories in gravity models predict that remoteness, as an "index of multilateral resistance" (Anderson and Wincoop, 2003), increases bilateral trade. Applying the same logic to RTAs, two remote countries (e.g. Australia and New Zealand) are more likely to form an RTA because they are unlikely to form RTAs with the rest of the world. The absolute differences in Polity scores, $\mathrm{CO} 2$ emission per capita (in logarithm) and the shares of child labor are used to account for the concerns about democracy, environment and labor standards in RTA formation. The rest of the covariates include common colonial relationship, military conflict intensity and political alliance. More details of these variables will be provided in the data section.

\subsection{Econometric Methodology}

Researchers usually resort to discrete choice regressions (e.g. probit or logit) for binary RTA data analysis. Baier and Bergstrand (2004) use a cross-sectional dataset (1996), focusing on the economic determinants of RTAs. Magee (2004) extends the analysis to a panel data setting and also considers some political variables. The ordinary binary choice analysis is acceptable in

\footnotetext{
${ }^{7}$ This can also be explained by the market access "insurance" motive (see, e.g., Perroni and Whalley, 1996; Fernandez and Portes, 1998) or the "terms of trade effect" (see, e.g., Bagwell and Staiger, 1999). Larger countries have bigger domestic markets and more power to manipulate terms of trade, so forming an RTA with a big country can insure the access to a big market and prevent the big country from manipulating terms of trade.
} 
cross section analysis if we assume most of the variations are time-invariant. A panel data analysis is usually better as it can provide richer information over time and is more capable to handle the problem of unobserved heterogeneity. The ordinary binary choice analysis, however, is inappropriate for panel data analysis because it assumes that the dependent variable (RTA dummy) is conditionally independent over time. For example, Mexico signed NAFTA with the U.S. and Canada in 1994, and NAFTA remains in place for all the following years. So the independence assumption is obviously violated. Traditional techniques dealing with temporal correlation will not help as the problem here is much more serious than serial correlation. This is a problem of exact correlation due to the irreversible nature of RTAs and will lead to serious bias.

This problem is addressed in this paper by a discrete time duration analysis. ${ }^{8}$ For the discrete RTA variable, this method is nothing new but standard complementary log-log (cloglog) or logistic regression. All we need is to drop all but the first positive outcome of the dependent variable for each country pair over the sample period (1960-2000). ${ }^{9}$ Once the repeated " 1 "s are dropped, the problem of conditional dependence in the standard logit analysis disappears. Please note that the event failure in this instance is two countries agreeing to a trade agreement and a spell is defined as the length of time until two countries form an agreement.

Jenkins $(1995,2004)$ shows that the maximum likelihood function for a discrete time duration analysis has exactly the same form as the standard likelihood function for a binary choice model. For a country pair $i j$, the "hazard" rate to sign an RTA in year $t$ is $h_{i j t}=\operatorname{Pr}\left[T_{i j}=t \mid T_{i j} \geq t-1\right]$, which is the probability the two countries sign an RTA in year $t$ conditional on that they have not signed the agreement by year $\mathrm{t}-1$. If we assume a cloglog hazard $h_{i j t}=1-\exp \left[-\exp \left(\beta^{\prime} \mathbf{X}_{i j t}+\theta_{t}\right)\right]$, where $\mathbf{X}$ are country or country-pair characteristics and $\theta_{t}$ is a transformation of the baseline hazard, we can run a cloglog regression on the amended dataset. This is an exact grouped duration analogue of the continuous time Cox proportional hazards model (see Prentice and Gloeckler, 1978; Jenkins, 2004).

We can also assume a logistic hazard $h_{i j t}=1 /\left[1+\exp \left(-\beta^{\prime} \mathbf{X}_{i j t}-\theta_{t}\right)\right]$ and run a logit regression. Logit link function also corresponds to an underlying continuous time duration model

\footnotetext{
${ }^{8}$ Depending on the nature of time intervals, there are continuous-time and discrete-time duration analysis. Discretetime analysis is more appropriate in this paper because time is grouped by year and there are a lot of ties in the data (i.e., many country pairs may be covered by RTAs in a year).

${ }^{9}$ An additional benefit of duration analysis is that it reduces the endogeneity problem of inequality. Keeping only the first positive outcome, we can hardly think of any feedback of RTAs on inequality.
} 
in which the within-interval durations follow a log-logistic distribution, but it imposes more complicated time-interactions than the proportional hazard model (Sueyoshi, 1995). It is easy to show that, when the probability of positive outcomes is small as in the case of RTAs, a cloglog link function is very close to a logistic link function. The two link functions are:

$\operatorname{cog} \log (P)=\log (A)$, where $A=-\log (1-P)$ and $P=\operatorname{Prob}(\mathrm{RTA}=1)$

$\operatorname{logit}(P)=\log (B)$, where $B=P /(1-P)$ is the odds ratio

If $P$ is very small, $A$ and $B$ are approximately the same. ${ }^{10}$ Because researchers are more familiar with logit than cloglog, we use logit in this paper. The corresponding cloglog regressions produce very similar results. We can run logit regressions separately for FTAs/CUs and PTAs. In the FTA/CU (PTA) regressions, we take all the spells without FTA/CU (PTA) as the default category. ${ }^{11}$ Alternatively, we can estimate FTAs/CUs and PTAs jointly as competing risks. Assuming independence of competing risks and a particular form for the hazards, Allison (1982) shows that the likelihood of the discrete time competing risks model has the same form as the likelihood for a standard multinomial logit model applied to the re-organized data after dropping repeated "1"s. In the multinomial logit, we study the duration of spells until either FTA/CU or PTA is formed, taking the no RTA case as the default category. The dependent variable has three values: 1 for FTA/CU; 2 for PTA; and 0 for the default case (no RTA). We estimate FTA/CU and PTAs both jointly in multinomial regressions and separately in logit regressions, but rely primarily on separate FTA/CU and PTA regressions due to the following reasons. Different from multinomial logit, separate logit regressions can handle better unobserved heterogeneity and does not assume independence of irrelevant alternatives (IIA). Moreover, in some of our regressions by sub-samples, it is impossible to run multinomial logit because most of the PTAs are dropped in some sub-samples.

We need take into account the duration dependence, i.e., the extent to which the conditional hazard of an RTA is rising or falling over time. ${ }^{12}$ If year dummies are used to account for duration dependence, all the years without any new RTA would be dropped because the year dummies perfectly predict these zero outcomes. To avoid this problem, we create a time counter to count the number of years already past since 1960 (the beginning of our sample), as well as its

\footnotetext{
${ }^{10} \mathrm{~A}=-\log (1-\mathrm{P})=\log (1 /(1-\mathrm{P}))=\log (1+\mathrm{P} /(1-\mathrm{P})) \approx \mathrm{P} /(1-\mathrm{P})=\mathrm{B}$. After we drop the repeated "1"s, positive outcomes account for only $0.3 \%$ and $0.45 \%$ respectively for FTAs/CUs and PTAs.

${ }^{11}$ Our results are very robust to several alternative definitions of the RTA variable. See section 7.2 for details.

${ }^{12}$ It also captures the "domino effect" of RTAs as suggested by Baldwin (1996).
} 
square, cubic terms and so on. Then this polynomial is used to account for the time dependence. The order of the polynomial is determined by the best fit of regressions. We will also consider the issue of unobserved heterogeneity in duration analysis. It is possible that some country pairs are more likely to form an RTA due to omitted variables. In duration analysis literature, the unobserved heterogeneity is called "frailty", analogous to the fixed effects or random effects in panel data. With frailty, the cloglog and logistic hazard functions become $h_{i j t}=1-\exp \left[-\exp \left(\beta \mathbf{X}_{i j t}+\theta_{t}+u\right)\right]$ and $h_{i j t}=1 /\left[1+\exp \left(-\beta \mathbf{X}_{i j t}-\theta_{t}-u\right)\right]$ respectively. If we assume a normal distribution for the unobserved heterogeneity $(u)$, we can use random effects cloglog or random effects logit. ${ }^{13}$

Duration analysis has been widely applied in economics such as duration of unemployment. Applications with similar data structure as RTAs in this paper have been found in international relations literature, such as Beck, Katz and Tucker (1998). They applied duration analysis to international disputes (a binary dependent variable) using a panel dataset over years 1951-1985. In the trade literature, duration analysis was only recently introduced to study the duration of trading relations as in Besedes and Prusa (2006) and RTA formation as in Liu (2008).

\section{Data}

This paper uses a large bilateral panel dataset covering years 1960-2000. Each observation is associated with two countries as a pair. A country pair appears only once in the data as singledyad (either $i j$ or $j i$ ). The dependent variable is a dummy variable, which is equal to one if two countries had an RTA in a year and zero otherwise. The Appendix lists the RTAs covered in this paper and the data sources. We include the RTAs notified to the GATT/WTO between 1960 and 2000, as well as some RTAs which were implemented but have not yet been notified to the WTO. ${ }^{14}$ The complexity of RTAs such as the non-uniform accession dates and suspensions are carefully considered. ${ }^{15}$

\footnotetext{
${ }^{13}$ No consistent fixed effect cloglog procedure is available. The fixed effect logit procedure (i.e. conditional logit) is available but inappropriate due to information loss. Because most of the country pairs have never signed any RTAs, they would be dropped in fixed effect logit regressions.

${ }^{14}$ Our RTA data are primarily based on the WTO RTA list as of May 1, 2004 (old list) and is updated by the new list as of July 18, 2007. Some of the agreements in the old list (e.g., the FTAs between EC and some East European countries) are still kept in the analysis although they are removed from the new list.

${ }^{15}$ For example, the Andean Community (a.k.a. CAN) has experienced lots of interruptions. See its history at: http://www.nationmaster.com/encyclopedia/Andean-Community
} 
Capital-labor ratio (capital stock per worker or $k$ ) data for years 1960-2000 are from Baier, Dwyer and Tamura (2006). Income inequality data (GINI coefficient and Q3) for the period 1960-1998 are from Dollar and Kraay (2002). ${ }^{16}$ The inequality data after 1998 are from World Development Indicators (WDI2003). The gaps of inequality data for some years are filled in by the weighted averages of the observed data in earlier and later years. ${ }^{17}$ Inequality data for some countries are extrapolated backward and forward to fill the missing data on both ends. ${ }^{18}$ GDP (PPP) data are from the Penn World Table 3.1. Bilateral trade flows are from the IMF Direction of Trade Statistics. Both GDP and trade data are measured in constant 1995 U.S. dollars. US GDP deflator data are from the IMF International Financial Statistics. Geographic data are from the 2003 CIA Fact Book. The great circle distances are constructed from the latitudes and longitudes of country pairs. The "remoteness" of a country is defined as the distance of the country to the rest of the world weighted by all the other countries' GDPs in a given year. The remoteness variable for a country pair (ij) in year $t$ is simply the product of the two countries' remoteness. "Island" and "Landlock" variables count respectively the number of island and landlocked countries in a pair (0/1/2). Child labor (i.e., percentage of child labor in 10-14 age group) and carbon dioxide emission per capita (CO2) data are from the WDI2003. Polity score data, measuring the degree of democracy, are from the Polity IV Project (Marshall and Jaggers, 2002). Other variables on colonial relationship, military conflict and alliance are also included. Common colony variable equals to unity if both have ever been colonized by the same third country and zero otherwise. Militarized Interstate Dispute Dataset (MID, Ghosn and Palmer, 2003) provides information on conflicts in which one or more states threatened, displayed, or used force against one or more other states between 1816 and 2001. They assign an ordinal number to each conflict, with higher number representing higher level of hostility. ${ }^{19}$ The Formal Alliance dataset (Gibler and Sarkees, 2004) seeks to identify each formal alliance between at least two states that fall into the classes of defense pact, neutrality or non-aggression treaty, or

\footnotetext{
${ }^{16}$ Although asset inequality is better, income inequality is used instead based on data availability. Income inequality (flow measure) and asset inequality (stock measure) are closely related.

${ }^{17}$ This method is reasonable, given the fact that changes in inequality generally follow smooth trajectories.

${ }^{18}$ The extrapolated data at least capture much of the between variations of GINI (Q3) across countries, which account for nearly $90 \%$ of total variations.

${ }^{19}$ Because the effect of military conflict may persist for many years after a conflict, we use the average hostility level for country pairs over 1946-2001 as a measure of conflict intensity after the World War II.
} 
entente agreement. Political ideology ("left" vs. "right") data are obtained from the Database of Political Institutions (DPI2000, Beck et al, 2001). ${ }^{20}$

Table 1 shows some descriptive statistics for these variables in year 2000, the latest year in our sample.

\section{Regression Results}

\subsection{The effects of inequality on RTA formation}

To address the temporal dependence problem of RTA variable, we apply a duration analysis (logit) using the amended dataset which drops all but the first positive outcomes for each country pair. ${ }^{21}$ In all of the duration regressions, the duration dependence term is captured by a polynomial of the time counter up to six-order based on the best fit of the regressions. Tables $2 \mathrm{~A}$ and 2B show the duration analysis (logit) results for FTAs/CUs and PTAs respectively.

The first two regressions include only the interaction terms and some commonly used covariates; while the other regressions include more covariates. In the last two columns, unobserved heterogeneity is considered by including country pair random effects. As expected, the sign pattern of $\beta_{1}$ and $\beta_{2}$ supports the median voter model in the FTA/CU regressions, while supports the lobbying model in the PTA regressions. Both $\beta_{1}$ and $\beta_{2}$ are highly significant. Considering unobserved heterogeneity ("frailty") does not cause large difference in the coefficients, but the likelihood-ratio test can not reject the null hypothesis of no unobserved heterogeneity.

How big is the magnitude of the effects of GINI and Q3 on RTA formation? Taking the coefficients from the duration analysis with frailty as an example (i.e., the last two columns of Tables $2 \mathrm{~A}$ and $2 \mathrm{~B}$ ), we can quantify the magnitude of the effects. The magnitude of $\beta_{1}$ and $\beta_{2}$ is similar in the FTA/CU and PTA regressions. Based on the last two FTA/CU regressions in Table $2 \mathrm{~A}$, it is on average about 0.0205 for GINI and 0.0615 for Q3 in absolute values. We define Odds_ratio $=P /(1-P)$, where $P=\operatorname{prob}(R T A=1)$. Taking derivative of $\ln ($ Odds_Ratio $)$ with respect to $G I N I_{i}$ yields:

$$
\frac{\partial \ln \left(\text { Odd } s_{-} \text {Ratio }\right)}{\partial G I N I_{i}}=\beta_{1} *\left[\log \left(k_{i}\right)-\log \left(k_{j}\right)\right]
$$

\footnotetext{
${ }^{20}$ DPI2000 covers 179 countries over years 1975-2000. The data before 1975 are assumed same as 1975 .

${ }^{21}$ Complementary log-log regressions give very similar results.
} 
Based on the mean value of the absolute difference in $\log (k)(=1.58$ in Table 1$),{ }^{22}$ the above partial derivative equals to 0.032. This says that one unit increase in GINI in a rich (poor) partner country decreases (increases) the odds of signing an RTA by $3.3 \%[\exp (0.032)-1=3.3 \%]$, ceteris paribus. By a similar calculation, one unit increase in Q3 in a rich (poor) partner country increases (decreases) the odds ratio by about $10 \%$, ceteris paribus. Q3's coefficient is much bigger than GINI's because the mean values of GINI and Q3 are very different (about 40 and 15 respectively, see Table 1). In terms of elasticity, they are not very different (about 1.3 for GINI and 1.5 for Q3). ${ }^{23}$ This implies that one percent change in GINI (Q3) can change the odds ratio of RTA formation by more than 1 percent. These magnitudes are significant economically and is even larger than the corresponding elasticity with respect to geographic distance - one of the most important determinants of RTAs (about 1.2 for FTAs/CUs and only 0.25-0.28 for PTAs based on the last two columns of Tables $2 \mathrm{~A}$ and $2 \mathrm{~B}) .{ }^{24}$ For example, if GINI increases by $33 \%$ from 45 (e.g. Peru, 1995) to 60 (e.g. Brazil, 1995), the odds ratio of an RTA will, on average, change by $1.3 * 33 \%=43 \%$, ceteris paribus. The results from PTA regressions offer a similar estimate.

We also estimate FTAs/CUs and PTAs jointly in multinomial logit regressions. The dependent variable is 1 for FTAs/CUs and 2 for PTAs, with 0 for the default cases of no RTA. The results are reported in Table 3. These results are not much different from the corresponding separate logit regressions in Tables $2 \mathrm{~A} \& 2 \mathrm{~B}$. The interpretations of these results are similar as well.

\subsection{The effects of other covariates on RTA formation}

Most of the coefficients of other covariates from duration analysis have the expected signs. Let us take the last two columns of Tables $2 \mathrm{~A}$ and $2 \mathrm{~B}$ as examples. The coefficient of $\mid \log \left(k_{i}\right)_{-}$ $\log \left(k_{j}\right) \mid$ is positive for FTAs/CUs, but negative for PTAs. One likely explanation is that the Heckscher-Ohlin effect dominates in the case of FTAs/CUs (i.e., countries with different capitallabor ratios can benefit more from trade and integration), but income effect dominates in the case of PTAs (i.e., a country prefers to sign an agreement with partners having similar income level).

\footnotetext{
${ }^{22}$ We should use the absolute value of the difference in $\log (\mathrm{k})$ or consider separately the cases when $\mathrm{k}_{\mathrm{i}}>\mathrm{k}_{\mathrm{j}}$ and $\mathrm{k}_{\mathrm{i}}<\mathrm{k}_{\mathrm{j}}$. The mean absolute values are roughly the same (1.58) if we consider the two cases separately.

${ }^{23}$ The elasticity of GINI is calculated as $0.032 /(1 / 40)=1.3$; the elasticity of Q3 is $0.1 /(1 / 15)=1.5$.

${ }^{24}$ See the next sub-section on the calculation of the elasticity with respect to distance.
} 
The sum and difference of GDP bear positive and negative signs respectively, implying that two large and similar countries are more likely to sign an RTA (i.e., "variety effect"). Countries that are closer in distance are more likely to form RTAs and the effect is stronger for FTAs/CUs than PTAs. Adjacent countries are more likely to form PTAs and island and landlocked countries are less likely to form PTAs, but these effects are insignificant for FTAs/CUs. Countries with similar polity scores are more likely to form FTAs/CUs, but less likely to form PTAs probably due to the very large dispersion of democracy levels among PTA partners. Countries with similar labor/environment standards are more likely to form FTAs/CUs. In the PTA regressions, environmental standard variable is negative and significant but labor standard variable is mostly insignificant. Countries ever colonized by the same parent countries are more likely to form PTAs but not significantly more likely to form FTAs/CUs. Hostility prevents countries from forming FTAs/CUs and formal alliance helps; while they are mostly insignificant in PTA regressions. Remoteness produces mixed results in FTA/CU and PTA regressions. ${ }^{25}$

We can also calculate the magnitude of coefficients of these covariates in terms of elasticities of the odds ratio. The calculation varies by variable types. First, most of the covariates are in logarithms (i.e., $\ln x, \ln \left(x_{\mathrm{i}}{ }^{*} x_{\mathrm{j}}\right)$ or $\left.\ln \left(x_{\mathrm{i}} / x_{\mathrm{j}}\right)\right)$, so their coefficients can be taken directly as the elasticities of the odds ratio with respect to $x,\left(x_{\mathrm{i}} * x_{\mathrm{j}}\right)$ or $\left(x_{\mathrm{i}} / x_{\mathrm{j}}\right)$ respectively. ${ }^{26}$ Second, the exponentiated coefficient of a dummy variable such as "Land Adjacency", "Common Colony" and "Alliance" measures the changes in $\ln ($ odds ratio) when the dummy variable changes from 0 to $1 .^{27}$ Finally, the exponentiated coefficient of a continuous variable in levels such as "Hostility" and "Remoteness" measures the changes in $\ln ($ odds ratio) when the variable increases by 1 . Their elasticities can be easily calculated in the same way as GINI/Q3.

\section{Auxiliary Regressions}

To reinforce our political economy interpretation of the results, we provide various auxiliary regressions in this section by studying some sub-samples of the data. We include the full set of

\footnotetext{
${ }^{25}$ The negative sign on remoteness in FTA/CU regressions is different from what theories predict, but is not uncommon in the literature. For example, Frankel, Stein and Wei (1997, p. 143) and Dalgin, Mitra and Trindade (2004), among many others, have similar finding in the gravity regressions for bilateral trade. Baier and Bergstrand (2004) find positive coefficient of remoteness for RTAs, but their remoteness measure is multiplied by the dummy variable indicating the same continent, so their explanation is different. Anyway, our main findings hold with and without the remoteness variable.

${ }^{26}$ For example, based on column (5) of Table 2A, the distance elasticity of the odds ratio in is -1.222 .

${ }^{27}$ The coefficients for "Island" and "Landlock" that take values $0 / 1 / 2$ can be understood in the similar way.
} 
covariates in these auxiliary regressions, but only report the coefficients of the key interaction terms to save space. The complete results are available upon request.

\subsection{Regressions by sub-samples based on the difference in capital-labor ratio}

The difference in capital-labor ratios varies for different country pairs. We expect that the distributional concerns are more important for the country pairs with different factor endowments. To test this, we first calculate the absolute difference in the average capital per worker of each country pair over the entire sample period (Dkpw) and then split the whole sample into two sub-samples: (1) country pairs that have greater than the median(Dkpw) (i.e., $\$ 12,957)$; and (2) the rest of the sample. We call the two sub-samples "differentiated country pairs" and "similar country pairs" respectively. Then we run the duration regressions using the sub-samples. The results are reported in Tables $4 \mathrm{~A}$ and $4 \mathrm{~B}$. The models do receive stronger support in the "differentiated country pairs" sub-sample compared to the "similar country pairs" sub-sample, as represented by the magnitude of the interaction terms' coefficients and the levels of their statistical significance.

\subsection{Political ideology and RTA formation}

We would expect that the empirical support for a model might be stronger in countries whose governments have certain ideological preferences (e.g., left or right oriented). A leftoriented government usually adopts pro-labor policies either because its constituents are workers or because it cares more about equality. On the contrary, a right-oriented government usually adopts pro-capital policies either because its constituents are capitalists or because it cares more about efficiency. It is standard in the political economy literature to use left-wing (right-wing) and pro-labor (pro-capital) interchangeably. Dutt and Mitra (2005) investigate the effects of ideology on trade policy and find that left-wing governments will adopt more protectionist policies in capital-rich countries but more pro-trade policies in labor-rich countries, as predicted by the Stolper-Samuelson theorem. Beck et al (2001) provide useful political ideology measures

in the Database of Political Institutions (DPI2000). Using the data from DPI2000, we define different sub-samples of the dataset according to governments' political ideology and expect that the median voter (lobbying) should receive stronger supports from the countries with leftoriented (right-oriented) governments. 
Table 5A reports the FTA/CU regression results based on two ideology sub-samples: the country pairs with both countries as left-oriented ("LL") and all of the other country pairs (i.e., "Rest"). ${ }^{28}$ All the regressions in Table 3 are logit with duration dependence and country pair random effects. Unobserved heterogeneity is insignificant in the "LL" sample, but significant in the "Rest" sample, as shown by the estimated "rho" on the last row. As expected, the median voter model does receive much stronger supports in the "LL" sample than in the "Rest" sample. $\beta_{1}$ and $\beta_{2}$ are more than three times bigger in the "LL" sample than in the "Rest" sample. The interaction terms actually turn insignificant in the last regression of Table 3 ("Rest" sample).

Table 5B reports the PTA regression results based on the following ideology sub-samples: the country pairs with both countries as right-oriented ("RR") and all of the other country pairs (i.e., "Rest"). As expected, the lobbying model receives stronger supports in the "RR" sample than in the "Rest" sample. Although the interactions terms are significant in all the regressions, $\beta_{1}$ and $\beta_{2}$ are two or three times bigger in the "RR" sample than in the "Rest" sample.

\subsection{Relating the estimated weight on social welfare to lobbying}

We relate the support of PTAs for the lobbying model to the estimated weight on social welfare by Gawande, Krishna and Olarreaga (2008). Using trade data of fifty countries, they quantify the weight that governments place on aggregate social welfare versus their private interests - the “ $\alpha$ ” parameter in the Grossman and Helpman (1994) "protection for sale" model. ${ }^{29}$ We expect that the support for the lobbying model in the PTA regressions should be stronger (weaker) if we restrict the countries to those with lower (higher) weight on social welfare.

We estimate the PTA regressions for countries with estimated $\alpha<5$ (low " $\alpha$ " sample) and the countries with $\alpha>5$ (high “ $\alpha$ ” sample). ${ }^{30}$ Higher $\alpha$ here implies higher weight on social welfare. The results are reported in Table 6A. As expected, the estimated coefficients of the interaction terms from the low " $\alpha$ ” sample regressions are two or three times larger than those

\footnotetext{
${ }^{28}$ Following Dutt and Mitra (2005), we use the ideological orientation ("Left", "Center", or "Right") of the chief executive for presidential systems, that of the largest government party for parliamentary systems, and the average of these two orientations for assembly-elected presidential systems. The political ideology variable in our data takes values $-1,-0.5,0,0.5$ and 1 , with higher value representing more left-oriented ideology. A regime is considered as left-oriented (right-oriented) if the value of the variable is negative (positive) and "center-oriented" if the value of the variable is zero.

${ }^{29}$ The estimates are taken from Table 1.1 in Gawande, Krishna and Olarreaga (2008). In the literature, several other papers such as Goldberg and Maggi (1999) among others also estimate $\alpha$, but each of these papers produces the estimate for only one country.

${ }^{30}$ The two countries having $\alpha$ close to the cutoff value are Peru (4.85) and Greece (5.11).
} 
reported in Table 2B; while the support from the high " $\alpha$ " sample is much weaker (insignificant in the GINI regression). These results imply that the support for lobbying model is closely related to governments' weight on social welfare versus interests groups.

We also try FTA/CU regressions by " $\alpha$ ” sub-samples and report the results in Table $6 \mathrm{~B}$. The interaction terms are insignificant in the low " $a$ " sub-sample. In the high " $a$ " sub-sample, the interaction terms are only marginally significant when GINI is used but insignificant when Q3 is used. The support for the median voter model is only slightly stronger in the high "a" sample than in the low "a" sample". This result is not surprising because majority interests may or may not be consistent with overall social welfare - a well known normative property of the median voter model.

\subsection{Sector coverage and its political economy implications}

The pro-labor (pro-capital) finding for FTAs/CUs (PTAs) is likely due to the stricter requirement under the Article XXIV than the Enabling Clause. Better coverage of trade leaves smaller room for lobbying and hence makes governments care more about general interests. In this sub-section, we explore alternative ways to support this argument. We measure the coverage of these agreements based on their coverage of service sectors. ${ }^{31}$ According to the GATS Article $\mathrm{V}$, service agreements had been signed along with or after some FTAs/CUs in goods. Signing such agreements signal the commitment of broader and deeper economic integration.

In Table 7, we restrict the full fledged RTAs to those with service agreements in the FTA/CU regressions. As expected, we find stronger support for the median voter model (e.g., much larger coefficients of the interaction terms) than in Table $2 \mathrm{~A} .{ }^{32}$ The result shows that sector coverage requirements seem to correspond to more concerns for general interests in RTA formation. This also implies that the exemptions and special treatments under the PTAs likely lead to greater influence of special interests. Therefore the different findings for FTAs/CUs and PTAs can be reasonably explained by the different requirements of GATT rules.

\section{Robustness checks and some related issues}

\footnotetext{
${ }^{31}$ Cadot, Olarreaga and Tschopp (2008) adopt the similar method to define effective RTAs. The list of RTAs with service coverage is based on the WTO RTA dated July 18, 2007. These service agreements are also called economic integration agreements (EIA) by the WTO.

${ }^{32}$ We do not run similar PTA regressions as no PTA covers service sectors.
} 
In this section, we provide some robustness checks and discuss some data and econometric issues related to RTA analysis.

\subsection{Alternative specifications for unobserved heterogeneity}

Prentice and Gloecker (1978) and Meyer (1990) propose a model for discrete time proportional hazards regression on grouped duration data, assuming that the unobserved heterogeneity follows a gamma mixture distribution. If convergence is obtained, this MLE procedure is supposed to be more efficient than random effects logit or cloglog, which uses quadrature to approximate the integral. We have tried this method, but obtained very similar results as those from random effects regressions. As additional robustness checks, we have also tried the Heckman and Singer-type nonparametric representations of frailty (Heckman and Singer, 1984) and again obtained very similar results.

\subsection{Redefining the default category of RTA and multinomial logit estimation}

In the previous regressions, FTAs/CUs and PTAs are considered in separate regressions; and the FTA/CU dummy is coded as zero when PTA is one and vice versa. In FTA/CU regressions, treating the country pairs with PTAs the same as non-RTA pairs in the default category seems acceptable as PTAs are only partial-scope agreements. One may worry about mixing FTAs/CUs with non-RTA cases as the default category in the PTA regressions. It turns out that this is not a problem at all because observations without any type of RTAs absolutely dominate those with RTAs. ${ }^{33}$ Therefore it does not matter how we code the other type of RTAs in regressions. To be assured, we have tried the following ways as robustness checks. First, we consider FATs/CUs and PTAs as two competing choices in multinomial logit regressions, taking the non-RTA case as the default category. The results are reported in Table 3 and they are very similar to those in Tables 2A and 2B. Second, in PTA regressions, we drop the observations when FTA/CU dummy equals to one, but obtain almost identical results as before. Finally, considering that the country pairs ever involved in an FTA/CU might be inherently different from non-RTA pairs even before signing the FTA/CU, we have tried eliminating all the country pairs that had ever involved in any FTA/CU during our sample period to avoid any

\footnotetext{
${ }^{33}$ After we drop the repeated "1"s, zero outcomes account for more than $99 \%$ of the observations.
} 
contamination effects of FTAs/CUs in PTAs regressions. ${ }^{34}$ Regressions using the revised data deliver very similar results as before. These results are not shown in the tables to save space.

\subsection{Partial observability of RTA decisions}

For the RTA dummy, we observe "1" when both partners want to sign an RTA, and zero when either country does not want to sign the RTA. When RTA dummy equals to zero, we only observe the product of two partners' decisions, rather than their individual preferences. This is a problem of "partial observability". With this problem, an increase in one country's willingness to sign an RTA, due to changes in its own inequality, does not necessarily imply an increase in the probability of signing the agreement if the other country is unwilling to sign the RTA.

This problem, however, only makes our decision in favor of the null hypothesis that inequality does not affect the probability of signing an RTA. Given that we have already found strong support for the median voter or lobbying model, the support would be even stronger were we able to solve the partial observability problem. Moreover, the possible bias in the coefficients due to the partial observability problem is alleviated by the fact that reciprocity and concessions are common practice in RTA formation. One country can request from or offer to its partner some "benefits" through international transfers or side-payments if one of them is unwilling to sign the agreement. For example, in order to conclude on the NAFTA, Mexico had to sign the side agreements on labor and environment standards proposed by the US. In this sense, an increase in the desirability of an RTA to one country alone can increase the probability of signing the agreement through international transfers, even if the other country does not want to sign it initially. Finally, the partial observability problem may be controlled for at least partially by the country pair random effects if this problem is country-pair specific. In sum, the previous duration analysis is still valid by testing the effects of each partner's inequality on joint RTA decisions. $^{35}$

\subsection{Left censoring of duration spells}

\footnotetext{
${ }^{34}$ This leads to $7.5 \%$ fewer observations in the regression.

${ }^{35}$ Liu (2008) is the first paper to address the partial observability problem in RTA literature. Applying the method suggested by Poirier (1980) and Abowd and Farber (1982), Liu (2008) finds that the median voter is still supported by FTAs/CUs. This procedure does not converge, however, in the case of PTAs.
} 
In duration analysis, we need know when countries becomes "at risk" of RTA formation. Countries might start to face the risk before 1960. Due to data limitation, however, our sample starts from 1960 and this creates the left censoring problem. Equally left censoring is irrelevant for the estimation of coefficients if no FTA formed before 1960, because the discrete hazard is a conditional probability and all the probabilities of the earlier years are conditioned out of the likelihood function (Jenkins, 1995, and Sueyoshi, 1995). Because the Treaty of Rome was signed in 1957, our method ignores the country pairs between the six original signatories of the EEC. But the subsequent accessions of other EC or EU members after 1960 are still kept in the analysis. Another problem is associated to those countries that enter the sample after 1960, such as the newly-independent countries from former colonies, the USSR or Yugoslavia. Most of these new states, however, are not covered in the sample due to missing covariate data. Overall the problem created by left censoring does not seem to be very critical.

\section{Concluding Remarks}

Applying a duration analysis to RTA data, this paper finds that the predictions of the median voter model is supported by FTA/CU formation; while the lobbying model seems to be more relevant in the case of PTAs. This finding helps us understand the underlying political economy rationales of different types of RTAs and offers some policy implications regarding the welfare effects of RTAs and the move from regionalism to multilateralism. It also lends support to the "substantially all the trade" requirement of the GATT Article XXIV on FTAs/CUs and points out the risk of lobbying behind the partial-scope PTAs.

It is important to note that the support for the median voter model does not mean that lobbying is absent in FTA/CU formation. For example, the prolonged staging periods of tariff reduction in most FTAs/CUs are likely due to lobbying by the import-competing sectors. ${ }^{36}$ The formation of FTAs/CUs, however, does require more stringent rules under the Article XXIV than PTAs under the Enabling Clause. Therefore FTA/CU decisions are less likely influenced by lobbying as compared to PTAs.

On the other hand, the support for the lobbying model in the case of PTAs does not mean that developing countries should not join hands at all to form PTAs. If an agreement is intended

\footnotetext{
${ }^{36}$ As shown in a study of NAFTA by Kowalczyk and Davis (1996), the sectors with the longest phase-out periods of tariffs in the U.S. are usually the import-competing sectors with the strongest lobbies.
} 
to promote development, cooperation in areas such as regulatory reform and infrastructure provision, or to increase bargaining power in international trade negotiations, then it may be appropriate. Regional cooperation, however, should be pursued independent of trade discrimination. In terms of trade promotion, we should not expect much gain from PTAs. Multilateral trade negotiations, unilateral adoption of international norms or RTAs with more stringent rules and comprehensive coverage of trade and sectors as required by the GATT Article XXIV may be more effective. ${ }^{37}$

\section{Reference}

Abowd, J., and H. Farber, 1982. Job queues and the union status of workers. Industrial and Labor Relations Review 35 (3), 354-367.

Allison, P., 1982. Discrete time methods for the analysis of event histories. In S. Leinhardt (ed) Sociological Methodology, Jossey-Bass, San Francisco.

Anderson, J., and E. van Wincoop, 2003. Gravity with gravitas: a solution of the Land Adjacency puzzle. American Economic Review 93 (1), 170-192.

Bagwell, K. and R. Staiger, 1999. An Economic Theory of GATT. American Economic Review 89(1): 215-248.

Baier, S.L., and J.H. Bergstrand, 2004. Economic determinants of free trade agreements. Journal of International Economics 64 (1), 29-63.

Baier, S.L., G.P. Dwyer, and R. Tamura, 2006. How Important Are Capital and Total Factor Productivity for Economic Growth? Economic Inquiry 44 (1), 23-49.

Baldwin, R., 1996. A domino theory of regionalism. NBER Working Paper No. 4465.

Beck, N., J.N. Katz, and R. Tucker, 1998. Taking time seriously: time-series-cross-section analysis with a binary dependent variable. American Journal of Political Science 42 (4), 12601288.

Beck, T., G. Clarke, A. Groff, and P. Keefer, 2001. New Tools and New Tests in Comparative Political Economy: The Database of Political Institutions. World Bank Economic Review 15(1), 165-176.

Besedes , T., and T.J. Prusa, 2006a. Ins, Outs, and the Duration of Trade. Canadian Journal of Economics 39(1): 266-295.

Bhagwati, J.N., 1993. "Regionalism and Multilateralism: An Overview," in Jaime De Melo and Arvind Panagariya, eds. New Dimensions in Regional Integration. Cambridge University Press.

Cadot, O., M. Olarreaga and J. Tschopp, 2008. Does Regionalism Reduce the Volatility of Trade Policy? Draft.

\footnotetext{
${ }^{37}$ Schiff and Winters (2003, page 264-265) also reach the same conclusion.
} 
Dalgin, M., and D. Mitra, V. Trindade, 2004. Inequality, nonhomothetic preferences, and trade: a gravity approach. NBER Working Paper No. 10800.

Dollar, D., and A. Kraay, 2002. Growth is good for the poor. Journal of Economic Growth 7 (3): 195-225.

Dutt, P., and D. Mitra, 2002. Endogenous trade policy through majority voting: an empirical investigation. Journal of International Economics 58(1): 107-133.

—, 2005. Political Ideology and Endogenous Trade Policy: An Empirical Investigation. Review of Economics and Statistics 87(1): 59-72.

Estevadeordal, A., C. Freund and E. Ornelas, 2008. Does Regionalism Affect Trade Liberalization towards Non-Members? Quarterly Journal of Economics 123(4), 1531-1575.

Fernandez, R. and J. Portes, 1998. Returns to Regionalism: An Evaluation of NonTraditional Gains from Regional Trade Agreements. World Bank Economic Review 12(2): 197220.

Frankel, J.A., E. Stein, and S.-J. Wei, 1997. Regional Trading Blocs. Institute for International Economics, Washington, DC.

Gawande, K., P. Krishna and M. Olarreaga, 2008. What Governments Maximize and Why: The View from Trade. Bush School Working Paper \# 604.

Ghosn, F., and G. Palmer, 2003. Codebook for the Militarized Interstate Dispute Data, Version 3.0. Online: http://cow2.la.psu.edu

Gibler, D.M., and M. Sarkees, 2004. Measuring Alliances: the Correlates of War Formal Interstate Alliance Dataset, 1816-2000. Journal of Peace Research, 41 (2), 211-222.

Goldberg, P., and Maggi, G., 1999. Protection for Sale: An Empirical Investigation, American Economic Review 89: 1135-1155.

Grossman, G.M., and E. Helpman, 1994. Protection for Sale. The American Economic Review 84(4), 833-850.

Grossman, G.M., and E. Helpman, 1995. The politics of free-trade agreements. American Economic Review 85(4), 667-690.

Heckman, J., and Singer, B., 1984. A Method for minimizing the impact of distributional assumptions in econometric models for duration data, Econometrica 52(2), 271-320.

Jenkins, S.P. 1995. Easy ways to estimate discrete time duration models. Oxford Bulletin of Economics and Statistics 57 (1), 129-138.

Jenkins S., 2004, Survival Analysis. http://www.iser.essex.ac.uk/teaching/degree/stephenj/ec968/pdfs/ec9681notesv5.pdf

Kowalczyk, C., and D. Davis, 1996. Tariff Phase Outs: Theory and Evidence from GATT and NAFTA. NBER Working Paper No. 5421.

Krishna, P., 1998, "Regionalism and Multilateralism: A Political Economy Approach." Quarterly Journal of Economics 113 (February), 227-251.

Levy, P., 1997. A political-economic analysis of free-trade agreements. American Economic Review 87 (4), 506-519.

Limao, N., and A. Panagariya. 2006. Inequality and Endogenous Trade Policy Outcomes. Journal of International Economics, forthcoming. 
Liu, X., 2007. A Political-economy Analysis of Free-trade Agreements: Comment. AER Internet Comment: http://www.aeaweb.org/aer/contents/icomments.html

Liu, X., 2008. The Political Economy of Free Trade Agreements: An Empirical Investigation. Journal of Economic Integration 23(2), 237-271.

Magee, C., 2003. Endogenous preferential trade agreements: an empirical analysis. Contributions to Economic Analysis \& Policy 2 (1), Article 15.

Maggi, G. and A. Rodriguez-Clare, 1998. The Value of Trade Agreements in the Presence of Political Pressures. Journal of Political Economy 106(3): 574-601

Maggi, G., and A. Rodríguez-Clare, 2007. A Political-Economy Theory of Trade Agreements. American Economic Review 97(4), 1374-1406.

Marshall, M.G., and K. Jaggers, 2002. Polity IV Project: Political Regime Characteristics and Transitions, 1800-2002.

Mayer, W., 1984. Endogenous tariff formation. American Economic Review 74(5), 970-985.

Meyer, B.D. 1990. Unemployment insurance and unemployment spells. Econometrica 58 (4), 757-782.

Mitra, D., 2002. Endogenous Political Organization and the Value of Trade Agreements. Journal of International Economics 57(2), 473-485.

Ornelas, E., 2005a. Endogenous Free Trade Agreements and the Multilateral Trading System. Journal of International Economics 67(2), 471-497.

-, 2005b. Rent Destruction and the Political Viability of Free Trade Agreements. Quarterly Journal of Economics 120(4), 1475-1506.

Panagariya, A., 1994. East Asian and the New Regionalism. The World Economy 17(6), 817-839.

Perroni, C. and J. Whalley, 1994. The new Regionalism: Trade Liberalization or Insurance? NBER Working Paper No. 4626.

Poirier, D.J., 1980. Partial observability in bivariate probit models. Journal of Econometrics 12, 209-217.

Prentice, R., L. Gloeckler, 1978, Regression analysis of grouped survival data with application to breast cancer data. Biometrics 34 (1), 57-67.

Rodrik, D., 1986. Tariffs, subsidies, and welfare with endogenous policy. Journal of International Economics 21(3/4), 285-299.

Schiff, M., and A. Winters, 2003. Regional Integration and Development. The World Bank and Oxford University Press.

Sueyoshi, G.T., 1995. A class of binary response models for grouped duration data. Journal of Applied Econometrics 10(4), 411-431.

Viner, J., 1950. The Customs Union Issue. Carnegie Endowment for International Peace, New York. 
Figure 1: Distribution of $\mathrm{K} / \mathrm{L}$ in an unequal country

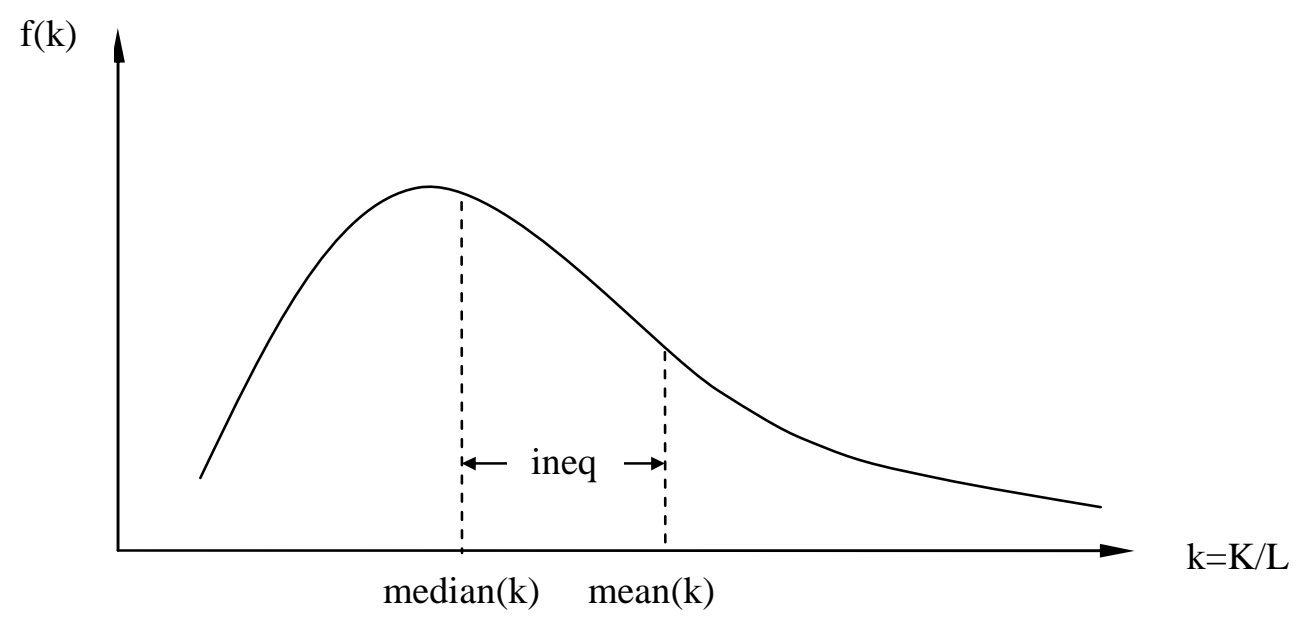

Table 1. Descriptive Statistics, Year 2000

\begin{tabular}{lrrrrrrrr}
\hline & \multicolumn{2}{c}{$\begin{array}{c}\text { Full Sample } \\
\text { (obs\#: } 5151 \text { ) }\end{array}$} & \multicolumn{2}{c}{$\begin{array}{c}\text { FTA/CU=1 } \\
\text { (obs\#: 445) }\end{array}$} & \multicolumn{2}{c}{$\begin{array}{c}\text { PTA=1 } \\
\text { (obs\#: 566) }\end{array}$} & \multicolumn{2}{c}{$\begin{array}{c}\text { RTA=0 } \\
\text { (obs\#: 4140) }\end{array}$} \\
\hline Variables & \multicolumn{1}{c}{ Mean } & \multicolumn{1}{c}{ S.D. } & Mean & S.D. & Mean & S.D. & Mean & S.D. \\
\hline RTAs & 0.20 & 0.40 & 1 & 0 & 1 & 0 & 0 & 0 \\
GiniA & 39.28 & 9.49 & 33.49 & 7.38 & 43.07 & 9.11 & 39.39 & 9.45 \\
GiniB & 39.61 & 9.76 & 34.98 & 9.25 & 43.36 & 7.99 & 39.60 & 9.82 \\
Q3A & 14.87 & 2.32 & 16.28 & 1.83 & 13.89 & 2.03 & 14.86 & 2.33 \\
Q3B & 14.95 & 2.29 & 16.00 & 2.22 & 14.10 & 1.65 & 14.95 & 2.33 \\
Diff. in log(k) & 1.58 & 1.22 & 0.73 & 0.56 & 1.23 & 0.95 & 1.72 & 1.26 \\
Sum of log(GDP) & 22.32 & 2.54 & 23.36 & 2.52 & 23.13 & 2.16 & 22.10 & 2.54 \\
Diff. in log(GDP) & 2.06 & 1.53 & 1.47 & 1.09 & 1.69 & 1.19 & 2.17 & 1.59 \\
log(distance) & 7.74 & 0.77 & 6.49 & 0.80 & 7.77 & 0.87 & 7.87 & 0.61 \\
Land Adjacency & 0.02 & 0.16 & 0.12 & 0.32 & 0.07 & 0.25 & 0.01 & 0.09 \\
Island (0/1/2) & 0.47 & 0.60 & 0.41 & 0.61 & 0.22 & 0.45 & 0.51 & 0.60 \\
Landlock (0/1/2) & 0.18 & 0.40 & 0.07 & 0.26 & 0.20 & 0.42 & 0.19 & 0.41 \\
Diff. in Polity & 5.82 & 5.02 & 3.07 & 4.49 & 5.84 & 4.71 & 6.12 & 5.02 \\
Diff. in Child Labor & 14.69 & 14.85 & 2.22 & 5.35 & 11.95 & 9.85 & 16.40 & 15.41 \\
Diff. in CO2 & 1.88 & 1.43 & 0.70 & 0.65 & 1.49 & 1.08 & 2.06 & 1.46 \\
Common Colonizer & 0.10 & 0.30 & 0.08 & 0.27 & 0.20 & 0.40 & 0.09 & 0.28 \\
Hostility & 0.01 & 0.09 & 0.02 & 0.10 & 0.02 & 0.16 & 0.01 & 0.08 \\
Alliance & 0.08 & 0.27 & 0.40 & 0.49 & 0.13 & 0.34 & 0.04 & 0.20 \\
Remoteness & 4.13 & 0.05 & 4.06 & 0.05 & 4.16 & 0.04 & 4.13 & 0.05 \\
\hline
\end{tabular}

Notes:

1. The data used in this table are based on year 2000, the latest year in our sample;

2. Only the observations with no missing data in any of the variables are covered (obs\#=5151);

3. RTAs includes both FTAs/CUs and PTAs signed by 2000;

4. "Diff." means absolute difference. 
Table 2A. Baseline duration analysis, FTAs/CUs

\begin{tabular}{|c|c|c|c|c|c|c|}
\hline & $(1)$ & $(2)$ & (3) & (4) & $(5)$ & (6) \\
\hline GINIi*(log $(\mathrm{ki})-\log (\mathrm{kj}))$ & $\begin{array}{l}-0.011 * * * \\
(0.004)\end{array}$ & & $\begin{array}{l}-0.020 * * * \\
(0.005)\end{array}$ & & $\begin{array}{l}-0.020 * * * \\
(0.005)\end{array}$ & \\
\hline GINIj*(log $(\mathrm{ki})-\log (\mathrm{kj}))$ & $\begin{array}{l}0.014 * * * \\
(0.004)\end{array}$ & & $\begin{array}{l}0.020 * * * \\
(0.005)\end{array}$ & & $\begin{array}{l}0.021 * * * \\
(0.004)\end{array}$ & \\
\hline $\mathrm{Q} 3 \mathrm{i} *(\log (\mathrm{ki})-\log (\mathrm{kj}))$ & & $\begin{array}{l}0.045^{* * * *} \\
(0.015)\end{array}$ & & $\begin{array}{l}0.061 * * \\
(0.025)\end{array}$ & & $\begin{array}{l}0.062 * * * \\
(0.020)\end{array}$ \\
\hline $\mathrm{Q} 3 \mathrm{j} *(\log (\mathrm{ki})-\log (\mathrm{kj}))$ & & $\begin{array}{l}-0.038 * * \\
(0.015)\end{array}$ & & $\begin{array}{l}-0.060 * * \\
(0.025)\end{array}$ & & $\begin{array}{l}-0.061 * * * \\
(0.020)\end{array}$ \\
\hline Diff. in $\log (\mathrm{k})$ & $\begin{array}{l}-0.565 * * * \\
(0.071)\end{array}$ & $\begin{array}{l}-0.572 * * * \\
(0.070)\end{array}$ & $\begin{array}{l}0.192 * \\
(0.106)\end{array}$ & $\begin{array}{l}0.211 * * \\
(0.105)\end{array}$ & $\begin{array}{l}0.185^{*} \\
(0.111)\end{array}$ & $\begin{array}{l}0.206^{*} \\
(0.110)\end{array}$ \\
\hline Sum of $\log (\mathrm{GDP})$ & $\begin{array}{l}0.235^{* * * *} \\
(0.020)\end{array}$ & $\begin{array}{l}0.233 * * * \\
(0.020)\end{array}$ & $\begin{array}{l}0.001 \\
(0.027)\end{array}$ & $\begin{array}{l}-0.004 \\
(0.027)\end{array}$ & $\begin{array}{l}0.004 \\
(0.029)\end{array}$ & $\begin{array}{l}-0.002 \\
(0.028)\end{array}$ \\
\hline Diff. in $\log (G D P)$ & $\begin{array}{l}-0.190 * * * \\
(0.045)\end{array}$ & $\begin{array}{l}-0.185^{* * *} \\
(0.044)\end{array}$ & $\begin{array}{l}-0.044 \\
(0.045)\end{array}$ & $\begin{array}{l}-0.041 \\
(0.045)\end{array}$ & $\begin{array}{l}-0.049 \\
(0.048)\end{array}$ & $\begin{array}{l}-0.045 \\
(0.047)\end{array}$ \\
\hline $\log ($ distance $)$ & $\begin{array}{l}-1.697 * * * \\
(0.075)\end{array}$ & $\begin{array}{l}-1.689 * * * \\
(0.075)\end{array}$ & $\begin{array}{l}-1.201 * * * \\
(0.087)\end{array}$ & $\begin{array}{l}-1.176^{* * * *} \\
(0.088)\end{array}$ & $\begin{array}{l}-1.222 * * * \\
(0.097)\end{array}$ & $\begin{array}{l}-1.193^{* * *} \\
(0.090)\end{array}$ \\
\hline Land Adjacency & & & $\begin{array}{l}-0.316 \\
(0.242)\end{array}$ & $\begin{array}{l}-0.280 \\
(0.240)\end{array}$ & $\begin{array}{l}-0.304 \\
(0.206)\end{array}$ & $\begin{array}{l}-0.268 \\
(0.204)\end{array}$ \\
\hline \# of Landlock (0/1/2) & & & $\begin{array}{l}-0.152 \\
(0.108)\end{array}$ & $\begin{array}{l}-0.157 \\
(0.108)\end{array}$ & $\begin{array}{l}-0.150 \\
(0.101)\end{array}$ & $\begin{array}{l}-0.156 \\
(0.100)\end{array}$ \\
\hline \# of Island $(0 / 1 / 2)$ & & & $\begin{array}{l}-0.270 \\
(0.210)\end{array}$ & $\begin{array}{l}-0.281 \\
(0.210)\end{array}$ & $\begin{array}{l}-0.264 \\
(0.205)\end{array}$ & $\begin{array}{l}-0.276 \\
(0.204)\end{array}$ \\
\hline Diff. in Polity & & & $\begin{array}{l}-0.048 * * * \\
(0.013)\end{array}$ & $\begin{array}{l}-0.050^{* * * *} \\
(0.013)\end{array}$ & $\begin{array}{l}-0.049 * * * \\
(0.011)\end{array}$ & $\begin{array}{l}-0.050^{* * * *} \\
(0.011)\end{array}$ \\
\hline Diff. in Child Labor & & & $\begin{array}{l}-0.033 * * * \\
(0.010)\end{array}$ & $\begin{array}{l}-0.032 * * * \\
(0.010)\end{array}$ & $\begin{array}{l}-0.033 * * * \\
(0.009)\end{array}$ & $\begin{array}{l}-0.032 * * * \\
(0.010)\end{array}$ \\
\hline Diff. in $\mathrm{CO} 2$ & & & $\begin{array}{l}-0.737 * * * \\
(0.109)\end{array}$ & $\begin{array}{l}-0.711 * * * \\
(0.107)\end{array}$ & $\begin{array}{l}-0.741 * * * \\
(0.099)\end{array}$ & $\begin{array}{l}-0.714 * * * \\
(0.098)\end{array}$ \\
\hline Common Colonizer & & & $\begin{array}{l}0.116 \\
(0.222)\end{array}$ & $\begin{array}{l}0.114 \\
(0.221)\end{array}$ & $\begin{array}{l}0.143 \\
(0.204)\end{array}$ & $\begin{array}{l}0.137 \\
(0.199)\end{array}$ \\
\hline Hostility & & & $\begin{array}{l}-0.842 * * \\
(0.367)\end{array}$ & $\begin{array}{l}-0.837 * * \\
(0.367)\end{array}$ & $\begin{array}{l}-0.888^{* *} \\
(0.444)\end{array}$ & $\begin{array}{l}-0.875 * * \\
(0.436)\end{array}$ \\
\hline Alliance & & & $\begin{array}{l}1.676 * * * \\
(0.185)\end{array}$ & $\begin{array}{l}1.674 * * * \\
(0.185)\end{array}$ & $\begin{array}{l}1.701 * * * \\
(0.146)\end{array}$ & $\begin{array}{l}1.695 * * * \\
(0.140)\end{array}$ \\
\hline Remoteness & & & $\begin{array}{l}-15.834 * * * \\
(1.592)\end{array}$ & $\begin{array}{l}-16.034 * * * \\
(1.609)\end{array}$ & $\begin{array}{l}-16.039 * * * \\
(1.526)\end{array}$ & $\begin{array}{l}-16.213^{* * * *} \\
(1.490)\end{array}$ \\
\hline Duration dependence & Yes & Yes & Yes & Yes & Yes & Yes \\
\hline $\begin{array}{l}\text { Dyad random effects } \\
\text { rho }\end{array}$ & & & & & $\begin{array}{l}\text { Yes } \\
0.022\end{array}$ & $\begin{array}{l}\text { Yes } \\
0.019\end{array}$ \\
\hline Log Likelihood & -2255 & -2257 & -1877 & -1883 & -1877 & -1883 \\
\hline Pseudo R2 & 0.304 & 0.303 & 0.383 & 0.381 & & \\
\hline Observations & 198417 & 198417 & 164949 & 164949 & 164949 & 164949 \\
\hline
\end{tabular}

Notes:

1. Standard errors in parentheses (clustered by countries pairs in regressions (1)-(4));

2. * significant at $10 \%$;** significant at $5 \%$; *** significant at $1 \%$;

3. Duration dependence is captured by a sixth order polynomial of the time counter. 
Table 2B. Baseline duration analysis, PTAs

\begin{tabular}{|c|c|c|c|c|c|c|}
\hline & (1) & (2) & (3) & (4) & (5) & (7) \\
\hline GINIi*(log $(\mathrm{ki})-\log (\mathrm{kj}))$ & $\begin{array}{l}0.014 * * * \\
(0.001)\end{array}$ & & $\begin{array}{l}0.011 * * * \\
(0.002)\end{array}$ & & $\begin{array}{l}0.011 * * * \\
(0.002)\end{array}$ & \\
\hline GINIj*(log $(\mathrm{ki})-\log (\mathrm{kj}))$ & $\begin{array}{l}-0.014 * * * \\
(0.001)\end{array}$ & & $\begin{array}{l}-0.012 * * * \\
(0.002)\end{array}$ & & $\begin{array}{l}-0.012 * * * \\
(0.002)\end{array}$ & \\
\hline $\mathrm{Q} 3 \mathrm{i}^{*}(\log (\mathrm{ki})-\log (\mathrm{kj}))$ & & $\begin{array}{l}-0.069 * * * \\
(0.005)\end{array}$ & & $\begin{array}{l}-0.067 * * * \\
(0.007)\end{array}$ & & $\begin{array}{l}-0.073 * * * \\
(0.008)\end{array}$ \\
\hline $\mathrm{Q} 3 \mathrm{j} *(\log (\mathrm{ki})-\log (\mathrm{kj}))$ & & $\begin{array}{l}0.068 * * * \\
(0.005)\end{array}$ & & $\begin{array}{l}0.065 * * * \\
(0.007)\end{array}$ & & $\begin{array}{l}0.070 * * * \\
(0.008)\end{array}$ \\
\hline Diff. in $\log (\mathrm{k})$ & $\begin{array}{l}-0.273 * * * \\
(0.035)\end{array}$ & $\begin{array}{l}-0.256 * * * \\
(0.035)\end{array}$ & $\begin{array}{l}-0.157 * * \\
(0.063)\end{array}$ & $\begin{array}{l}-0.166 * * * \\
(0.061)\end{array}$ & $\begin{array}{l}-0.192 * * * \\
(0.069)\end{array}$ & $\begin{array}{l}-0.206 * * * \\
(0.068)\end{array}$ \\
\hline Sum of $\log (\mathrm{GDP})$ & $\begin{array}{l}0.106^{* * * *} \\
(0.011)\end{array}$ & $\begin{array}{l}0.116^{* * * *} \\
(0.012)\end{array}$ & $\begin{array}{l}0.159 * * * \\
(0.016)\end{array}$ & $\begin{array}{l}0.165^{* * * *} \\
(0.016)\end{array}$ & $\begin{array}{l}0.191 * * * \\
(0.019)\end{array}$ & $\begin{array}{l}0.199 * * * \\
(0.019)\end{array}$ \\
\hline Diff. in $\log (\mathrm{GDP})$ & $\begin{array}{l}-0.202 * * * \\
(0.029)\end{array}$ & $\begin{array}{l}-0.203 * * * \\
(0.028)\end{array}$ & $\begin{array}{l}-0.259 * * * \\
(0.029)\end{array}$ & $\begin{array}{l}-0.266 * * * \\
(0.030)\end{array}$ & $\begin{array}{l}-0.297 * * * \\
(0.033)\end{array}$ & $\begin{array}{l}-0.301 * * * \\
(0.033)\end{array}$ \\
\hline $\log ($ distance $)$ & $\begin{array}{l}0.009 \\
(0.052)\end{array}$ & $\begin{array}{l}0.020 \\
(0.053)\end{array}$ & $\begin{array}{l}-0.245^{* * * *} \\
(0.074)\end{array}$ & $\begin{array}{l}-0.222 * * * \\
(0.074)\end{array}$ & $\begin{array}{l}-0.281 * * * \\
(0.075)\end{array}$ & $\begin{array}{l}-0.254 * * * \\
(0.075)\end{array}$ \\
\hline Land Adjacency & & & $\begin{array}{l}0.829 * * * \\
(0.240)\end{array}$ & $\begin{array}{l}0.859 * * * \\
(0.241)\end{array}$ & $\begin{array}{l}0.941 * * * \\
(0.240)\end{array}$ & $\begin{array}{l}0.975 * * * \\
(0.239)\end{array}$ \\
\hline \# of Landlock (0/1/2) & & & $\begin{array}{l}-0.797 * * * \\
(0.107)\end{array}$ & $\begin{array}{l}-0.809 * * * \\
(0.108)\end{array}$ & $\begin{array}{l}-0.928 * * * \\
(0.111)\end{array}$ & $\begin{array}{l}-0.940 * * * \\
(0.112)\end{array}$ \\
\hline \# of Island $(0 / 1 / 2)$ & & & $\begin{array}{l}-0.302 * * * \\
(0.095)\end{array}$ & $\begin{array}{l}-0.261 * * * \\
(0.094)\end{array}$ & $\begin{array}{l}-0.361 * * * \\
(0.103)\end{array}$ & $\begin{array}{l}-0.317 * * * \\
(0.103)\end{array}$ \\
\hline Diff. in Polity & & & $\begin{array}{l}0.024 * * * \\
(0.007)\end{array}$ & $\begin{array}{l}0.026 * * * \\
(0.007)\end{array}$ & $\begin{array}{l}0.026 * * * \\
(0.007)\end{array}$ & $\begin{array}{l}0.028 * * * \\
(0.007)\end{array}$ \\
\hline Diff. in Child Labor & & & $\begin{array}{l}0.006 \\
(0.004)\end{array}$ & $\begin{array}{l}0.007 \\
(0.004)\end{array}$ & $\begin{array}{l}0.007 \\
(0.005)\end{array}$ & $\begin{array}{l}0.009^{*} \\
(0.005)\end{array}$ \\
\hline Diff. in $\mathrm{CO} 2$ & & & $\begin{array}{l}-0.175^{* * * *} \\
(0.052)\end{array}$ & $\begin{array}{l}-0.166 * * * \\
(0.051)\end{array}$ & $\begin{array}{l}-0.171 * * * \\
(0.055)\end{array}$ & $\begin{array}{l}-0.163 * * * \\
(0.055)\end{array}$ \\
\hline Common Colonizer & & & $\begin{array}{l}0.294 * * * \\
(0.110)\end{array}$ & $\begin{array}{l}0.324 * * * \\
(0.112)\end{array}$ & $\begin{array}{l}0.376 \text { *** } \\
(0.115)\end{array}$ & $\begin{array}{l}0.416 * * * \\
(0.116)\end{array}$ \\
\hline Hostility & & & $\begin{array}{l}-0.534 \\
(0.412)\end{array}$ & $\begin{array}{l}-0.531 \\
(0.411)\end{array}$ & $\begin{array}{l}-0.564 \\
(0.358)\end{array}$ & $\begin{array}{l}-0.564 \\
(0.358)\end{array}$ \\
\hline Alliance & & & $\begin{array}{l}-0.069 \\
(0.148)\end{array}$ & $\begin{array}{l}-0.041 \\
(0.149)\end{array}$ & $\begin{array}{l}-0.087 \\
(0.154)\end{array}$ & $\begin{array}{l}-0.051 \\
(0.155)\end{array}$ \\
\hline Remoteness & & & $\begin{array}{l}14.443 * * * \\
(0.873)\end{array}$ & $\begin{array}{l}14.037 * * * \\
(0.876)\end{array}$ & $\begin{array}{l}16.926^{* * * *} \\
(1.053)\end{array}$ & $\begin{array}{l}16.382 * * * \\
(1.060)\end{array}$ \\
\hline Duration dependence & Yes & Yes & Yes & Yes & Yes & Yes \\
\hline $\begin{array}{l}\text { Dyad random effects } \\
\text { rho }\end{array}$ & & & & & $\begin{array}{l}\text { Yes } \\
0.192 * * *\end{array}$ & $\begin{array}{l}\text { Yes } \\
0.191 * * *\end{array}$ \\
\hline Log Likelihood & -3769 & -3743 & -3412 & -3387 & -3400 & -3375 \\
\hline Pseudo R2 & 0.203 & 0.208 & 0.257 & 0.262 & & \\
\hline Observations & 194097 & 194097 & 160609 & 160609 & 160609 & 160609 \\
\hline
\end{tabular}

Notes:

1. Standard errors in parentheses (clustered by countries pairs in regressions (1)-(4));

2. * significant at $10 \%$;* significant at $5 \%$; *** significant at $1 \%$;

3. Duration dependence is captured by a fifth order polynomial of the time counter. 
Table 3: Estimating FTAs/CUs and PTAs jointly, multinomial logit

\begin{tabular}{|c|c|c|c|c|}
\hline \multirow{3}{*}{$\mathrm{GINI}^{*}(\log (\mathrm{ki})-\log (\mathrm{kj}))$} & \multicolumn{2}{|c|}{ mlogit regression using Gini } & \multicolumn{2}{|c|}{ mlogit regression using Q3 } \\
\hline & FTA/CU & PTA & FTA/CU & PTA \\
\hline & $\begin{array}{l}-0.018 * * * \\
(0.005)\end{array}$ & $\begin{array}{l}0.012 * * * \\
(0.002)\end{array}$ & & \\
\hline GINIj*(log $(\mathrm{ki})-\log (\mathrm{kj}))$ & $\begin{array}{l}0.018 * * * \\
(0.005)\end{array}$ & $\begin{array}{l}-0.012 * * * \\
(0.002)\end{array}$ & & \\
\hline Q3i*(log $(\mathrm{ki})-\log (\mathrm{kj}))$ & & & $\begin{array}{l}0.048 * \\
(0.025)\end{array}$ & $\begin{array}{l}-0.068 * * * \\
(0.007)\end{array}$ \\
\hline $\mathrm{Q} 3 \mathrm{j} *(\log (\mathrm{ki})-\log (\mathrm{kj}))$ & & & $\begin{array}{l}-0.048 * \\
(0.025)\end{array}$ & $\begin{array}{l}0.067 * * * \\
(0.007)\end{array}$ \\
\hline Diff. in $\log (\mathrm{k})$ & $\begin{array}{l}0.240 * * \\
(0.107)\end{array}$ & $\begin{array}{l}-0.161 * * * \\
(0.062)\end{array}$ & $\begin{array}{l}0.268 * * \\
(0.105)\end{array}$ & $\begin{array}{l}-0.169 * * * \\
(0.061)\end{array}$ \\
\hline Sum of $\log (\mathrm{GDP})$ & $\begin{array}{l}0.028 \\
(0.028)\end{array}$ & $\begin{array}{l}0.162 * * * \\
(0.016)\end{array}$ & $\begin{array}{l}0.023 \\
(0.027)\end{array}$ & $\begin{array}{l}0.168 * * * \\
(0.016)\end{array}$ \\
\hline Diff. in $\log (G D P)$ & $\begin{array}{l}-0.063 \\
(0.046)\end{array}$ & $\begin{array}{l}-0.263 * * * \\
(0.029)\end{array}$ & $\begin{array}{l}-0.061 \\
(0.046)\end{array}$ & $\begin{array}{l}-0.270 * * * \\
(0.030)\end{array}$ \\
\hline $\log ($ distance $)$ & $\begin{array}{l}-1.265 * * * \\
(0.089)\end{array}$ & $\begin{array}{l}-0.331 * * * \\
(0.074)\end{array}$ & $\begin{array}{l}-1.238 * * * \\
(0.090)\end{array}$ & $\begin{array}{l}-0.308 * * * \\
(0.074)\end{array}$ \\
\hline Land Adjacency & $\begin{array}{l}-0.235 \\
(0.231)\end{array}$ & $\begin{array}{l}0.914 * * * \\
(0.239)\end{array}$ & $\begin{array}{l}-0.200 \\
(0.230)\end{array}$ & $\begin{array}{l}0.946 * * * \\
(0.240)\end{array}$ \\
\hline \# of Landlock $(0 / 1 / 2)$ & $\begin{array}{l}-0.246^{* *} \\
(0.110)\end{array}$ & $\begin{array}{l}-0.904 * * * \\
(0.110)\end{array}$ & $\begin{array}{l}-0.256^{* *} \\
(0.110)\end{array}$ & $\begin{array}{l}-0.914 * * * \\
(0.111)\end{array}$ \\
\hline \# of Island $(0 / 1 / 2)$ & $\begin{array}{l}-0.308 \\
(0.215)\end{array}$ & $\begin{array}{l}-0.285 * * * \\
(0.096)\end{array}$ & $\begin{array}{l}-0.321 \\
(0.215)\end{array}$ & $\begin{array}{l}-0.245 * * * \\
(0.095)\end{array}$ \\
\hline Diff. in Polity & $\begin{array}{l}-0.048 * * * \\
(0.013)\end{array}$ & $\begin{array}{l}0.022 * * * \\
(0.007)\end{array}$ & $\begin{array}{l}-0.049 * * * \\
(0.013)\end{array}$ & $\begin{array}{l}0.024 * * * \\
(0.007)\end{array}$ \\
\hline Diff. in Child Labor & $\begin{array}{l}-0.028 * * * \\
(0.010)\end{array}$ & $\begin{array}{l}0.007 \\
(0.004)\end{array}$ & $\begin{array}{l}-0.026^{* *} \\
(0.010)\end{array}$ & $\begin{array}{l}0.008^{*} \\
(0.004)\end{array}$ \\
\hline Diff. in $\mathrm{CO} 2$ & $\begin{array}{l}-0.775 * * * \\
(0.111)\end{array}$ & $\begin{array}{l}-0.186 * * * \\
(0.052)\end{array}$ & $\begin{array}{l}-0.753 * * * \\
(0.110)\end{array}$ & $\begin{array}{l}-0.176 * * * \\
(0.052)\end{array}$ \\
\hline Common Colonizer & $\begin{array}{l}0.235 \\
(0.215)\end{array}$ & $\begin{array}{l}0.278 * * \\
(0.110)\end{array}$ & $\begin{array}{l}0.233 \\
(0.215)\end{array}$ & $\begin{array}{l}0.305 * * * \\
(0.111)\end{array}$ \\
\hline Hostility & $\begin{array}{l}-0.810^{* *} \\
(0.394)\end{array}$ & $\begin{array}{l}-0.550 \\
(0.397)\end{array}$ & $\begin{array}{l}-0.798 * * \\
(0.396)\end{array}$ & $\begin{array}{l}-0.552 \\
(0.399)\end{array}$ \\
\hline Alliance & $\begin{array}{l}1.611 \text { *** } \\
(0.187)\end{array}$ & $\begin{array}{l}-0.049 \\
(0.144)\end{array}$ & $\begin{array}{l}1.613 * * * \\
(0.187)\end{array}$ & $\begin{array}{l}-0.022 \\
(0.145)\end{array}$ \\
\hline Remoteness & $\begin{array}{l}-14.097 * * * \\
(1.647)\end{array}$ & $\begin{array}{l}13.664 * * * \\
(0.879)\end{array}$ & $\begin{array}{l}-14.327 * * * \\
(1.659)\end{array}$ & $\begin{array}{l}13.207 * * * \\
(0.881)\end{array}$ \\
\hline Duration dependence & & & & \\
\hline Pseudo R2 & & & & \\
\hline Log Likelihood & & & & \\
\hline Observations & & & & 34 \\
\hline
\end{tabular}

Notes:

1. The left panel corresponds to column (3) in Tables $2 \& 3$ respectively;

2. The right panel corresponds to column (4) in Tables $2 \& 3$ respectively;

3. Standard errors in parentheses;

4. * significant at $10 \%$; ** significant at $5 \%$; *** significant at $1 \%$;

5. Duration dependence is captured by a sixth order polynomial of the time counter. 
Table 4A. FTA/CU sub-samples by difference in capital per worker (Dkpw)

\begin{tabular}{|c|c|c|c|c|}
\hline \multirow[b]{3}{*}{$\mathrm{GINI}_{\mathrm{i}}^{*}\left(\log \left(\mathrm{k}_{\mathrm{i}}\right)-\log \left(\mathrm{k}_{\mathrm{j}}\right)\right)$} & \multicolumn{2}{|c|}{ Differentiated Country Pairs } & \multicolumn{2}{|c|}{ Similar Country Pairs } \\
\hline & (1) & (2) & (3) & (4) \\
\hline & $\begin{array}{l}-0.044 * * * \\
(0.005)\end{array}$ & & $\begin{array}{l}-0.004 \\
(0.011)\end{array}$ & \\
\hline $\operatorname{GINI}_{\mathrm{j}} *\left(\log \left(\mathrm{k}_{\mathrm{i}}\right)-\log \left(\mathrm{k}_{\mathrm{j}}\right)\right)$ & $\begin{array}{l}0.045 * * * \\
(0.005)\end{array}$ & & $\begin{array}{l}0.006 \\
(0.011)\end{array}$ & \\
\hline $\mathrm{Q} 3_{\mathrm{i}} *\left(\log \left(\mathrm{k}_{\mathrm{i}}\right)-\log \left(\mathrm{k}_{\mathrm{j}}\right)\right)$ & & $\begin{array}{l}0.177 * * * \\
(0.023)\end{array}$ & & $\begin{array}{l}0.009 \\
(0.051)\end{array}$ \\
\hline $\mathrm{Q} 3_{\mathrm{j}}^{*}\left(\log \left(\mathrm{k}_{\mathrm{i}}\right)-\log \left(\mathrm{k}_{\mathrm{j}}\right)\right)$ & & $\begin{array}{l}-0.179 * * * \\
(0.024)\end{array}$ & & $\begin{array}{l}-0.003 \\
(0.052)\end{array}$ \\
\hline Other covariates & Yes & Yes & Yes & Yes \\
\hline Duration dependence & Yes & Yes & Yes & Yes \\
\hline Log Likelihood & -837 & -858 & -949 & -949 \\
\hline Pseudo R2 & 0.452 & 0.438 & 0.373 & 0.373 \\
\hline Observations & 81966 & 81966 & 82983 & 82983 \\
\hline
\end{tabular}

Notes:

1. Robust standard errors in parentheses (clustered by country pairs);

2. * significant at $10 \%$; ** significant at $5 \%$; *** significant at $1 \%$;

3. Duration dependence is captured by a fifth or sixth order polynomial of the time counter;

4. Regressions (1) \& (2) use the sub-sample with Dkpw > $\$ 12,957$;

5. Regressions (3) \& (4) use the sub-sample with Dkpw $<=\$ 12,957$.

Table 4B. PTA sub-samples by difference in capital per worker (Dkpw)

\begin{tabular}{|c|c|c|c|c|}
\hline \multirow[b]{3}{*}{$\mathrm{GINI}_{\mathrm{i}}^{*}\left(\log \left(\mathrm{k}_{\mathrm{i}}\right)-\log \left(\mathrm{k}_{\mathrm{j}}\right)\right)$} & \multicolumn{2}{|c|}{ Differentiated Country Pairs } & \multicolumn{2}{|c|}{ Similar Country Pairs } \\
\hline & (1) & (2) & (3) & (4) \\
\hline & $\begin{array}{l}0.016 * * * \\
(0.003)\end{array}$ & & $\begin{array}{l}-0.003 \\
(0.002)\end{array}$ & \\
\hline $\mathrm{GINI}_{\mathrm{j}}^{*}\left(\log \left(\mathrm{k}_{\mathrm{i}}\right)-\log \left(\mathrm{k}_{\mathrm{j}}\right)\right)$ & $\begin{array}{l}-0.015^{* * *} \\
(0.002)\end{array}$ & & $\begin{array}{l}0.001 \\
(0.002)\end{array}$ & \\
\hline $\mathrm{Q} 3_{\mathrm{i}} *\left(\log \left(\mathrm{k}_{\mathrm{i}}\right)-\log \left(\mathrm{k}_{\mathrm{j}}\right)\right)$ & & $\begin{array}{l}-0.080 * * * \\
(0.010)\end{array}$ & & $\begin{array}{l}-0.009 \\
(0.011)\end{array}$ \\
\hline $\mathrm{Q} 3_{\mathrm{j}}{ }^{*}\left(\log \left(\mathrm{k}_{\mathrm{i}}\right)-\log \left(\mathrm{k}_{\mathrm{j}}\right)\right)$ & & $\begin{array}{l}0.080 * * * \\
(0.010)\end{array}$ & & $\begin{array}{l}0.003 \\
(0.011)\end{array}$ \\
\hline Other covariates & Yes & Yes & Yes & Yes \\
\hline Duration dependence & Yes & Yes & Yes & Yes \\
\hline Log Likelihood & -1081 & -1060 & -2265 & -2265 \\
\hline Pseudo R2 & 0.289 & 0.303 & 0.248 & 0.248 \\
\hline Observations & 81306 & 81306 & 79303 & 79303 \\
\hline
\end{tabular}

Notes:

1. Robust standard errors in parentheses (clustered by country pairs);

2. * significant at $10 \%$;** significant at $5 \%$; *** significant at $1 \%$;

3. Duration dependence is captured by a fifth or sixth order polynomial of the time counter;

4. Regressions (1) \& (2) use the sub-sample with Dkpw > $\$ 12,957$;

5. Regressions (3) \& (4) use the sub-sample with Dkpw $<=\$ 12,957$. 
Table 5A. FTA/CU sub-samples by political ideology

\begin{tabular}{|c|c|c|c|c|}
\hline \multirow[b]{3}{*}{$\mathrm{GINI}_{\mathrm{i}} *\left(\log \left(\mathrm{k}_{\mathrm{i}}\right)-\log \left(\mathrm{k}_{\mathrm{j}}\right)\right)$} & \multicolumn{2}{|c|}{ "LL" sub-sample } & \multicolumn{2}{|c|}{ "Rest" sub-sample } \\
\hline & (1) & (2) & (3) & (4) \\
\hline & $\begin{array}{l}-0.037 * * * \\
(0.006)\end{array}$ & & $\begin{array}{l}-0.014 * * \\
(0.006)\end{array}$ & \\
\hline $\mathrm{GINI}_{\mathrm{j}}^{*}\left(\log \left(\mathrm{k}_{\mathrm{i}}\right)-\log \left(\mathrm{k}_{\mathrm{j}}\right)\right)$ & $\begin{array}{l}0.036 * * * \\
(0.006)\end{array}$ & & $\begin{array}{l}0.016 * * \\
(0.006)\end{array}$ & \\
\hline $\mathrm{Q} 3_{\mathrm{i}} *\left(\log \left(\mathrm{k}_{\mathrm{i}}\right)-\log \left(\mathrm{k}_{\mathrm{j}}\right)\right)$ & & $\begin{array}{l}0.136 * * * \\
(0.024)\end{array}$ & & $\begin{array}{l}0.047 \\
(0.030)\end{array}$ \\
\hline $\mathrm{Q} 3_{\mathrm{j}} *\left(\log \left(\mathrm{k}_{\mathrm{i}}\right)-\log \left(\mathrm{k}_{\mathrm{j}}\right)\right)$ & & $\begin{array}{l}-0.145 * * * \\
(0.025)\end{array}$ & & $\begin{array}{l}-0.043 \\
(0.030)\end{array}$ \\
\hline Other covariates & Yes & Yes & Yes & Yes \\
\hline Duration dependence & Yes & Yes & Yes & Yes \\
\hline Pseudo R2 & 0.432 & 0.430 & 0.377 & 0.376 \\
\hline Log Likelihood & -400 & -402 & -1449 & -1452 \\
\hline Observations & 27132 & 27132 & 137817 & 137817 \\
\hline
\end{tabular}

Notes:

1. Robust standard errors in parentheses (clustered by country pairs);

2. * significant at $10 \%$; * significant at $5 \%$; *** significant at $1 \%$;

3. Duration dependence is captured by a fifth or sixth order polynomial of the time counter;

4. Regressions (1) \& (2) use the sub-sample with both countries as "left-oriented";

5. Regressions (3) \& (4) use the sub-sample not covered by Regressions (1) \& (2).

Table 5B. PTA sub-samples by political ideology

\begin{tabular}{|c|c|c|c|c|}
\hline \multirow[b]{3}{*}{$\mathrm{GINI}_{\mathrm{i}} *\left(\log \left(\mathrm{k}_{\mathrm{i}}\right)-\log \left(\mathrm{k}_{\mathrm{j}}\right)\right)$} & \multicolumn{2}{|c|}{ "RR" sub-sample } & \multicolumn{2}{|c|}{ "Rest" sub-sample } \\
\hline & (1) & (2) & (3) & (4) \\
\hline & $\begin{array}{l}0.029 * * * \\
(0.006)\end{array}$ & & $\begin{array}{l}0.009 * * * \\
(0.002)\end{array}$ & \\
\hline $\mathrm{GINI}_{\mathrm{j}} *\left(\log \left(\mathrm{k}_{\mathrm{i}}\right)-\log \left(\mathrm{k}_{\mathrm{j}}\right)\right)$ & $\begin{array}{l}-0.027 * * * \\
(0.006)\end{array}$ & & $\begin{array}{l}-0.010 * * * \\
(0.002)\end{array}$ & \\
\hline $\mathrm{Q} 3_{\mathrm{i}} *\left(\log \left(\mathrm{k}_{\mathrm{i}}\right)-\log \left(\mathrm{k}_{\mathrm{j}}\right)\right)$ & & $\begin{array}{l}-0.103 * * * \\
(0.027)\end{array}$ & & $\begin{array}{l}-0.063 * * * \\
(0.007)\end{array}$ \\
\hline $\mathrm{Q} 3_{\mathrm{j}} *\left(\log \left(\mathrm{k}_{\mathrm{i}}\right)-\log \left(\mathrm{k}_{\mathrm{j}}\right)\right)$ & & $\begin{array}{l}0.103 * * * \\
(0.026)\end{array}$ & & $\begin{array}{l}0.060 * * * \\
(0.007)\end{array}$ \\
\hline Other covariates & Yes & Yes & Yes & Yes \\
\hline Duration dependence & Yes & Yes & Yes & Yes \\
\hline Log Likelihood & -496.9 & -499.3 & -2856 & -2833 \\
\hline Pseudo R2 & 0.249 & 0.246 & 0.273 & 0.278 \\
\hline Observations & 20165 & 20165 & 140444 & 140444 \\
\hline
\end{tabular}

Notes:

1. Robust standard errors in parentheses (clustered by country pairs);

2. * significant at $10 \%$; ** significant at $5 \%$; *** significant at $1 \%$;

3. Duration dependence is captured by a fourth or fifth order polynomial of the time counter;

4. Regressions (1) \& (2) use the sub-sample with both countries as "right-oriented";

5. Regressions (3) \& (4) use the sub-sample not covered by Regressions (1) \& (2). 
Table 6A. PTA sub-sample by the weights on social welfare (a)

\begin{tabular}{|c|c|c|c|c|}
\hline \multirow[b]{3}{*}{ GINIi*(log $(\mathrm{ki})-\log (\mathrm{kj}))$} & \multicolumn{2}{|c|}{$a<5$} & \multicolumn{2}{|c|}{$a>5$} \\
\hline & $(1)$ & $(2)$ & (3) & (4) \\
\hline & $\begin{array}{l}0.033 * * * \\
(0.006)\end{array}$ & & $\begin{array}{l}0.001 \\
(0.002)\end{array}$ & \\
\hline GINIj*(log $(\mathrm{ki})-\log (\mathrm{kj}))$ & $\begin{array}{l}-0.035 * * * \\
(0.006)\end{array}$ & & $\begin{array}{l}-0.001 \\
(0.002)\end{array}$ & \\
\hline Q3i*(log $(\mathrm{ki})-\log (\mathrm{kj}))$ & & $\begin{array}{l}-0.149 * * * \\
(0.024)\end{array}$ & & $\begin{array}{l}-0.027 * * * \\
(0.009)\end{array}$ \\
\hline Q3j*(log $(\mathrm{ki})-\log (\mathrm{kj}))$ & & $\begin{array}{l}0.140 * * * \\
(0.023)\end{array}$ & & $\begin{array}{l}0.028 * * * \\
(0.009)\end{array}$ \\
\hline Other covariates & Yes & Yes & Yes & Yes \\
\hline Duration dependence & Yes & Yes & Yes & Yes \\
\hline Log Likelihood & -559.8 & -557.9 & -1072 & -1068 \\
\hline Pseudo R2 & 0.322 & 0.324 & 0.231 & 0.233 \\
\hline Observations & 11799 & 11799 & 83009 & 83009 \\
\hline
\end{tabular}

Notes:

1. Robust standard errors in parentheses (clustered by country pairs);

2. * significant at $10 \%$;* significant at $5 \%$; *** significant at $1 \%$;

3. Duration dependence is captured by an up to sixth order polynomial of the time counter.

Table 6B. FTA/CU sub-sample by the weights on social welfare $(a)$

\begin{tabular}{|c|c|c|c|c|}
\hline \multirow[b]{3}{*}{ GINIi*(log $(\mathrm{ki})-\log (\mathrm{kj}))$} & \multicolumn{2}{|c|}{$a<5$} & \multicolumn{2}{|c|}{$a>5$} \\
\hline & (1) & (2) & (3) & (4) \\
\hline & $\begin{array}{l}-0.028 \\
(0.026)\end{array}$ & & $\begin{array}{l}-0.014^{*} \\
(0.008)\end{array}$ & \\
\hline GINIj*(log $(\mathrm{ki})-\log (\mathrm{kj}))$ & $\begin{array}{l}0.035 \\
(0.028)\end{array}$ & & $\begin{array}{l}0.014 * \\
(0.008)\end{array}$ & \\
\hline $\mathrm{Q} 3 \mathrm{i}^{*}(\log (\mathrm{ki})-\log (\mathrm{kj}))$ & & $\begin{array}{l}-0.040 \\
(0.092)\end{array}$ & & $\begin{array}{l}0.028 \\
(0.038)\end{array}$ \\
\hline $\mathrm{Q} 3 \mathrm{j} *(\log (\mathrm{ki})-\log (\mathrm{kj}))$ & & $\begin{array}{l}0.044 \\
(0.087)\end{array}$ & & $\begin{array}{l}-0.030 \\
(0.038)\end{array}$ \\
\hline Other covariates & Yes & Yes & Yes & Yes \\
\hline Duration dependence & Yes & Yes & Yes & Yes \\
\hline Log Likelihood & -64.74 & -65.32 & -1186 & -1188 \\
\hline Pseudo R2 & 0.458 & 0.453 & 0.395 & 0.394 \\
\hline Observations & 10307 & 10307 & 82249 & 82249 \\
\hline
\end{tabular}

Notes:

1. Robust standard errors in parentheses (clustered by country pairs);

2. * significant at $10 \%$; ** significant at $5 \%$; *** significant at $1 \%$;

3. Duration dependence is captured by an up to seventh order polynomial of the time counter. 
Table 7. FTA/CU sub-sample with service coverage (GATS Article V)

\begin{tabular}{lll}
\hline & $(1)$ & $(2)$ \\
\hline GINIi*(log(ki) $-\log (\mathrm{kj}))$ & $-0.042^{* * * *}$ & \\
GINIj*(log $(\mathrm{ki})-\log (\mathrm{kj}))$ & $(0.011)$ & \\
& $0.044 * * *$ & \\
$\mathrm{Q} 3 \mathrm{i}^{*}(\log (\mathrm{ki})-\log (\mathrm{kj}))$ & & $0.131^{* * *}$ \\
& & $(0.039)$ \\
$\mathrm{Q} 3 \mathrm{j}^{*}(\log (\mathrm{ki})-\log (\mathrm{kj}))$ & & $-0.126^{* * *}$ \\
& & $(0.039)$ \\
Other covariates & Yes & Yes \\
Duration dependence & Yes & Yes \\
Log Likelihood & -543 & -545 \\
Pseudo R2 & 0.377 & 0.375 \\
Observations & 168045 & 168045 \\
\hline
\end{tabular}

Notes:

1. Robust standard errors in parentheses (clustered by country pairs);

2. * significant at $10 \%$; ** significant at $5 \%$; *** significant at $1 \%$;

3. Duration dependence is captured by a sixth order polynomial of the time counter. 
Appendix: List of RTAs covered in this paper (1960-2000)

\begin{tabular}{|c|c|c|c|c|c|}
\hline Agreement Name & Eff. Date & Type & Agreement Name & Eff. Date & Type \\
\hline $\mathrm{EC}$ & 1-Jan-58 & $\mathrm{CU}$ & CIS & 30-Dec-94 & FTA \\
\hline EFTA & 3-May-60 & FTA & CARICOM-Colombia & 1-Jan-95 & PTA \\
\hline CACM (FTA prior1995) & $12-$-Oct-61 & $\mathrm{CU}$ & EC-Estonia & 1-Jan-95 & FTA \\
\hline CACM-Costa Rica & 1-Jan-62 & FTA & EC-Latvia & 1-Jan-95 & FTA \\
\hline Chana-Burkina Faso & 1-Jan-62 & FTA & EC-Lithuania & 1-Jan-95 & FTA \\
\hline $\mathrm{ACM}$ & 1-Jan-64 & $\mathrm{CU}$ & Mexico-Costa Rica & 1-Jan-95 & FTA \\
\hline TRIPARTITE & 1-Apr-68 & PTA & SAPTA & 7-Dec-95 & PTA \\
\hline EC-Switzerland & 1-Jan-73 & FTA & EC-Turkey & 1-Jan-96 & $\mathrm{CU}$ \\
\hline PTN & 11-Feb-73 & PTA & Estonia-Ukraine & 14-Mar-96 & FTA \\
\hline EC-Norway & 1-Jul-73 & FTA & EFTA-Estonia & 1-Jun-96 & FTA \\
\hline CARICOM (FTA prior 1995) & 1-Aug-73 & $\mathrm{CU}$ & EFTA-Latvia & 1-Jun-96 & FTA \\
\hline MRU & 1-Jan-74 & $\mathrm{CU}$ & EFTA-Lithuania & 1-Aug-96 & FTA \\
\hline CEPGL & 1-Jan-76 & FTA & Canada-Israel & 1-Jan-97 & FTA \\
\hline Bangkok Agreement & 17-Jun-76 & PTA & Poland-Lithuania & 1-Jan-97 & FTA \\
\hline EC-Algeria & 1-Jul-76 & FTA & Slovak-Israel & 1-Jan-97 & FTA \\
\hline PATCRA & $1-\mathrm{Feb}-77$ & FTA & Turkey-Israel & 1-May-97 & FTA \\
\hline SPARTECA & 1-Jan-81 & PTA & Slovak-Latvia & 1-Jul-97 & FTA \\
\hline LAIA & 18-Mar-81 & PTA & Slovak-Lithuania & 1-Jul-97 & FTA \\
\hline CER & 1-Jan-83 & FTA & Canada-Chile & 5-Jul-97 & FTA \\
\hline ECCAS & 1-Jan-85 & FTA & Arab Free Trade Area & 1-Jan-98 & FTA \\
\hline $\mathrm{ECO}$ & 1-Jan-85 & PTA & Mexico-Nicaragua & 1-Jan-98 & FTA \\
\hline US-Israel & 19-Aug-85 & FTA & Hungary-Israel & 1-Feb-98 & FTA \\
\hline EFTA-Finland & 1-Jan-86 & FTA & Slovak-Estonia & 12-Feb-98 & FTA \\
\hline CAN (Andean Community) & 25-May-88 & PTA & EC-Tunisia & 1-Mar-98 & FTA \\
\hline AMU & 1-Jan-89 & FTA & Poland-Israel & 1-Mar-98 & FTA \\
\hline US-Canada & 1-Jan-89 & FTA & Turkey-Lithuania & 1-Mar-98 & FTA \\
\hline GSTP & 19-Apr-89 & PTA & Hungary-Turkey & 1-Apr-98 & FTA \\
\hline MERCOSUR & 29-Nov-91 & PTA & Estonia-Turkey & 1-Jun-98 & FTA \\
\hline AFTA & 28-Jan-92 & PTA & Slovak-Turkey & 1-Sep-98 & FTA \\
\hline EC-Hungary & 1-Mar-92 & FTA & Bulgaria-Turkey & 1-Jan-99 & FTA \\
\hline EC-Poland & 1-Mar-92 & FTA & CACM-Chile & 1-Jan-99 & FTA \\
\hline EC-Slovak & 1-Mar-92 & FTA & Poland-Latvia & 1-Jun-99 & FTA \\
\hline EFTA-Turkey & 1-Apr-92 & FTA & Chile-Mexico & 1-Aug-99 & FTA \\
\hline EFTA-Slovak & 1-Jul-92 & FTA & EFTA-Morocco & 1-Dec-99 & FTA \\
\hline ECOWAS & 1-Jan-93 & FTA & EC-South Africa & 1-Jan-00 & FTA \\
\hline EFTA-Israel & 1-Jan-93 & FTA & Hungary-Latvia & 1-Jan-00 & FTA \\
\hline CEFTA & 1-Mar-93 & FTA & WAEMU & 1-Jan-00 & PTA \\
\hline Armenia-Russian Fed & 25-Mar-93 & FTA & EC-Morocco & 1-Mar-00 & FTA \\
\hline EFTA-Bulgaria & 1-Jul-93 & FTA & Hungary-Lithuania & 1-Mar-00 & FTA \\
\hline EFTA-Hungary & 1-Oct-93 & FTA & Poland-Turkey & 1-May-00 & FTA \\
\hline EFTA-Poland & 15-Nov-93 & FTA & EC-Israel & 1-Jun-00 & FTA \\
\hline EC-Bulgaria & 31-Dec-93 & FTA & EC-Mexico & 1-Jul-00 & FTA \\
\hline NAFTA & 1-Jan-94 & FTA & Mexico-Israel & 1-Jul-00 & FTA \\
\hline BAFTA & 1-Apr-94 & FTA & Turkey-Latvia & 1-Jul-00 & FTA \\
\hline COMESA & 8-Dec-94 & PTA & EAC & 7-Jul-00 & PTA \\
\hline
\end{tabular}

Notes: All the subsequent accessions of other members to EEC, EC and EU by 2000 are covered in our analysis, although they are not shown individually listed in the table. The service agreements are not treated as separate agreements. An agreements into force before July 15 of a year (inclusive) is considered as effective in this year, and considered as the following year otherwise.

Data Sources: (1). WTO: http://www.wto.org/english/tratop_e/region_e/region_e.htm (dated May 1, 2004 and July 18, 2007); (2). WTO Archive, WTO, Geneva, Switzerland; (3). Frankel, Stein and Wei (1997); (4). Schiff and Winters (2003); (5). Foreign Trade Information System: http://www.sice.oas.org/agreements_e.asp (accessed in 2004) 